NOTICE: This is the author's version of a work that was accepted for publication in Chemical Engineering Journal. Changes resulting from the publishing process, such as peer review, editing, corrections, structural formatting and other quality control mechanisms may not be reflected in this document. Changes may have been made to this work since it was submitted for publication. A definitive version was subsequently published in Chemical Engineering Journal, Volume 226, 15 June 2013, Pages 336-347. http://doi.org/10.1016/j.cej.2013.04.070 


\section{Accepted Manuscript}

Review

Adsorptive remediation of environmental pollutants using novel graphenebased nanomaterials

Shaobin Wang, Hongqi Sun, H.M. Ang, M.O. Tadé

PII:

S1385-8947(13)00548-2

DOI: http://dx.doi.org/10.1016/j.cej.2013.04.070

Reference: CEJ 10685

To appear in:

\section{Chemical Engineering Journal}

Received Date:

6 March 2013

Revised Date:

16 April 2013

Accepted Date:

17 April 2013

Please cite this article as: S. Wang, H. Sun, H.M. Ang, M.O. Tadé, Adsorptive remediation of environmental pollutants using novel graphene-based nanomaterials, Chemical Engineering Journal (2013), doi: http://dx.doi.org/ 10.1016/j.cej.2013.04.070

This is a PDF file of an unedited manuscript that has been accepted for publication. As a service to our customers we are providing this early version of the manuscript. The manuscript will undergo copyediting, typesetting, and review of the resulting proof before it is published in its final form. Please note that during the production process errors may be discovered which could affect the content, and all legal disclaimers that apply to the journal pertain. 


\title{
Adsorptive remediation of environmental pollutants using novel graphene-based nanomaterials
}

\author{
Shaobin Wang, ${ }^{*}$ Hongqi Sun, H.M. Ang, M. O. Tadé \\ Department of Chemical Engineering and CRC for Contamination Assessment and Remediation of \\ the Environment (CRC-CARE), Curtin University, GPO Box U1987, Perth, WA 6845, Australia \\ *Correspondence author. E-mail: Shaobin.wang@curtin.edu.au
}

\begin{abstract}
Pollution of air, water and soil is a worldwide issue for the eco-environment and human society. Removal of various pollutants including inorganic and organic compounds from the environment is a big challenge. Adsorption techniques are usually simple and work effectively. However, the adsorption capacities of materials depend on their porous structure and surface properties. Graphene oxide and graphene are new carbonaceous nanomaterials. Graphene has a large theoretical specific surface area and graphene oxide has functional groups, indicating their potential for the adsorption processes. In the past few years, many investigations have been focused on the applications of graphene or composites in removal of pollutants from air and water. In this paper, we will review recent advances in graphene-related nanomaterials for adsorptive treatment of environmental pollution. Graphene oxide possesses several functional groups and strong acidity, exhibiting high adsorption for basic compounds and cations while graphene shows hydrophobic surface and presents high adsorption to chemicals due to strong $\pi-\pi$ interaction. Modification of graphene oxide or graphene with metal oxides or organics can produce various nanocomposites, enhancing adsorption capacity and separation efficiency. Activation of graphene into porous carbonaceous material will be a promising way to further enhance adsorption capacity.
\end{abstract}

Key words: Adsorption; graphene oxide; graphene; pollutants; activation 


\section{Contents}

1. Introduction.

2. Synthesis and structure of GO and GNs.

3. Adsorptive removal of gas pollutants.

4.

Water treatment by GO or GNs adsorption.

4.1 Inorganic metal/metalloid cations.

4.2 Inorganic anions.

4.3 Organic dyes.

4.4 Other organic pollutants.

5. Conclusion and perspectives.

Acknowledgement

References

\section{Introduction}

Since the industrial revolution, rapid developments in industrialization, population expansion, and urbanization have largely contributed to the severe pollution to air, water and soil. A vast of pollutants discharged from industrial processes and households annually have caused significant effects on the eco-environment and human life. These pollutants include toxic gases $\left(\mathrm{NO}_{\mathrm{x}}, \mathrm{SO}_{\mathrm{x}}\right.$, $\mathrm{CO}, \mathrm{NH}_{3}$ ), heavy metals, organics and bio-toxics. A number of physical, chemical and biological technologies have been developed to control the pollution successfully [1-6]. Among the various available technologies, adsorption process is widely used and considered as a simple and easy operation and it can effectively remove different types of pollutant from the environment $[7,8]$. In addition, adsorption does not result in secondary pollution by producing harmful substances during the process.

For any adsorption process, an adsorbent having large surface area, pore volume, and proper functionalities is the key to success. Currently, many different porous materials have been developed, such as activated carbon, pillared clays, zeolites, mesoporous oxides, polymers and metal-organic frameworks, showing varying extent of effectiveness in removing the toxic pollutants from air, water and soil [8-12]. Among them, carbonaceous-based adsorbents including activated carbon, carbon nanotubes, and fullerene usually show high adsorption capacity and thermal stability [13-16].

In the past a few years, graphene oxide (GO) and graphene nanosheets (GNs) have attracted tremendous interest in the world. Graphene is a two-dimensional carbon nanomaterial with single layer of $s p^{2}$-hybridized carbon atoms arranged in six-membered rings. Graphene has strong 
mechanical, thermal, and electrical properties, with a theoretical value of specific surface area at $2630 \mathrm{~m}^{2} / \mathrm{g}$ [17]. GO is functionalized graphene with varying oxygen-containing groups. Several reviews have been reported on applications of GO and GNs in different areas such as physics, chemistry, biology, and materials science [17-21], however, few reviews on graphene-based materials as adsorbents for pollutant removal is available [22]. In this paper, we will review the research in graphene-based nanomaterials as adsorbents for removal of various types of contaminant in air and water systems.

\section{Synthesis and structure of GO and GNs}

Currently, most GO is synthesized by chemical oxidation and exfoliation of pristine graphite using either the Brodie, Staudenmaier, or Hummers method, or some variations of these methods. Brodie first found that the oxidizing mixture $\left(\mathrm{KClO}_{4}+\right.$ fuming $\left.\mathrm{HNO}_{3}\right)$ could form $\mathrm{GO}$ only with graphitizable carbons that contain regions of graphitic structure [23]. Staudenmaier then reported the formation of $\mathrm{GO}$ when graphite was heated with $\mathrm{H}_{2} \mathrm{SO}_{4}, \mathrm{HNO}_{3}$, and $\mathrm{KClO}_{4}$ [24]. Later, Hummers and Offeman introduced a convenient method to prepare GO using $\mathrm{H}_{2} \mathrm{SO}_{4}$ and $\mathrm{KMnO}_{4}$ [25]. The following diagram shows the preparation processes of the above three methods.

(1) Brodie method

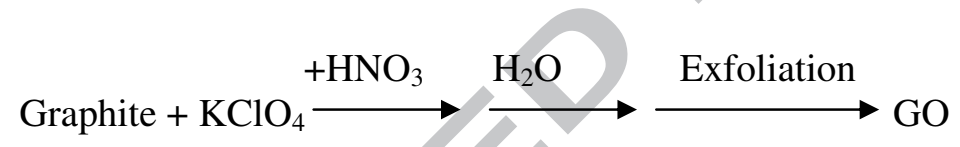

$60{ }^{\circ} \mathrm{C}$

(2) Staudenmaier method

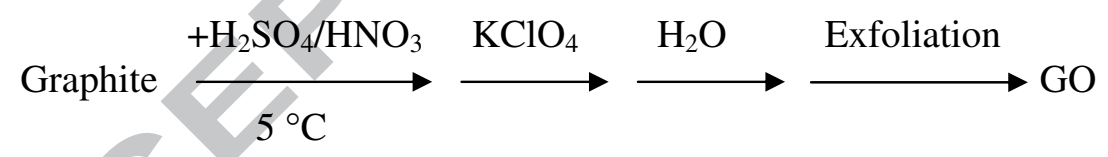

(3) Hummers-Offeman method

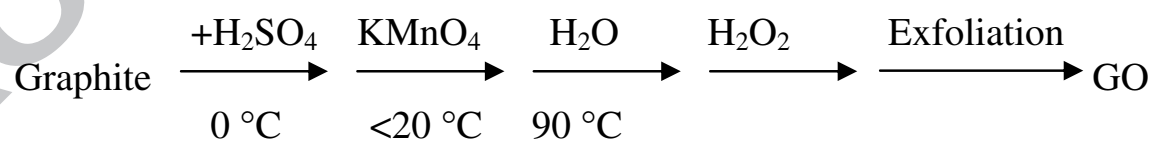

Scheme 1 Synthesis processes of graphene oxide.

Exfoliation is an important step in GO synthesis and is usually achieved in liquid solution using ultrasonic method with different solvents $[26,27]$. The typical procedures involve exposure of graphite or graphite oxide powders to particular solvents, and then exposing these solutions to 
sonication. Recently, other methods were also developed for simultaneously exfoliation and reduction of GO to obtain GNs, such as thermal treatment [28], chemical method [29], plasma[30], and microwave [31].

GO usually has several oxygen-containing groups, such as carboxylic, hydroxyl, and epoxide functional groups on carbon surface. It is believed that GO is a nonstoichiometric compound with a variety of compositions depending on the synthesis conditions. In spite of extensive scientific investigations, the exact composition and structure of chemically synthesized GO are still questionable. Different structural models, which correspond to an ideal formula of $\mathrm{C}_{8} \mathrm{O}_{2}(\mathrm{OH})_{2}$, have been advanced. Its models are based either on a wrinkled carbon sheet composed of trans-linked cyclohexane chairs with oxygenated surface groups (Ruess model), on Lerf's epoxide-containing GO structure or on the keto/enol structure proposed by Scholz and Boehm [32]. Szabo et al. [33] proposed a new model based on several techniques. Fig.1 shows the different GO structural models proposed by some researchers. It is generally believed that the important properties of GO are its layered structure and negatively charged surface, which can provide a wide applications in adsorption.

Fig.1 Various models of GO chemical structure.

The functionalized GO can be reduced to GNs with partial restoration of the $\mathrm{sp}^{2}$-hybridized network. Up to now, considerable efforts have been devoted to developing the reduction methods using different reducing reagents under thermal, chemical, electrochemical, photothermal, photocatalytic, sonochemical, microwave, laser, and plasmas conditions [34]. However, GNs from different reduction methods will show varying properties. In addition, many other methods have been reported for direct synthesis of GNs, such as micromechanical cleavage of graphite, chemical vapour deposition (CVD), epitaxial growth, and substrate-free gas phase synthesis, etc., however, these methods usually need high temperature, high-quality substrate materials and accurate control over cooling rates, which are impractical for a large scale manufacturing [35]. Typical XRD patterns, Raman spectra, FTIR and UV-vis spectra of GO and GNs are shown in Fig.2 [36].

Significant differences in physicochemical properties between GO and reduced GO were observed in terms of crystal structure, defective structure, surface functional groups and optical property. GO is an electrically insulating material due to their disrupted $\mathrm{sp}^{2}$ bonding networks. Owing to the structure deformation and the presence of covalently bonded functional groups, GO sheets are atomically rough. GO also has highly defective regions that affect the electrical transport. After reduction, the oxygen-containing groups are removed and the conjugated network of the graphitic lattice is recovered. An ideal sheet of graphene consists of only trigonally bonded $\mathrm{sp}^{2}$ carbon atoms and is perfectly flat. In general, GNs present hydrophobicity and are difficult to disperse in water. 
Therefore, surface modification by chemical, covalent and noncovalent functionalization can be made to prepare composites for a wide application of GNs.

Fig.2 XRD patterns (a), Raman spectra (b), FTIR spectra (c) and UV-vis spectra (d) of GO and GNs.

\section{Adsorptive removal of gas pollutants}

Air pollutants include toxic gases and particulates. $\mathrm{NO}_{\mathrm{x}}, \mathrm{SO}_{\mathrm{x}}, \mathrm{H}_{2} \mathrm{~S}, \mathrm{NH}_{3}, \mathrm{CO}$, and volatile organic compounds (VOCs) are the most important gaseous pollutants, which can cause significant damages to the eco-environment and human health. A traditional method for polluted air remediation is adsorption using solid adsorbents such as highly porous zeolites [37-39] and activated carbon [40-43]. In the past years, it was found that GO, GNs and their modified forms can also be good adsorbents for reactive removal of these toxic gases. However, most of investigations focused on ammonia adsorption using GO, GNs and metal oxide modified composites. Few investigations also reported adsorptive removal of sulphur compounds and VOCs.

Unlike other carbonaceous materials, GO has a layered structure with strong acidity and can be used for reactive adsorption of basic gases. Seredych and Bandosz [44, 45] first tested ammonia adsorption on GO. They observed a very high ammonia adsorption on GO (61 mg/g) due to surface chemistry and geometry. Since ammonia is a basic gas, the acid-base interactions with surface functional groups located at the edges of the carbon layers play an important role for the adsorption. Petit et al. [46] further compared two GO samples synthesized from the Hummers-Offeman and Brodie methods for ammonia adsorption and found that ammonia adsorption is strongly related to the type of GO. Intercalation of ammonia in the interlayer space of GO and reactive adsorption were observed. For GO prepared by the Brodie method, ammonia was retained by reaction with the carboxylic groups at the edges of the graphene layers while for the GO from the Hummers method, the reaction with the epoxy and carboxylic groups was responsible.

Seredych et al. [47] then prepared two GNs from the reduction of GO and found different texture and chemistry of the materials significantly affect their capacity in ammonia adsorption. The adsorption capacity is much linked to the presence of surface epoxides, which can react with ammonia leading to the formation of amines. Creation of porosity after reduction did not enhance ammonia adsorption, implying the importance of chemical adsorption. Tang and Cao [48] employed density functional theory calculations to study adsorption and dissociation of ammonia on GO and GNs and concluded that the adsorption of $\mathrm{NH}_{3}$ on GO is generally stronger than that on GNs because of the presence of diverse active defect sites, such as the hydroxyl and epoxy functional 
groups and their neighbouring carbon atoms, which shows a good agreement with the above experimental observations.

Apart from single GO and GNs, various composites with GO or GNs were also prepared and tested for $\mathrm{NH}_{3}$ adsorption. In the composites, metal oxides were introduced to GO layered structure, which can improve porosity and acid groups. Petit and Bandosz [49] prepared GO/polyoxometalate nanocomposites and reported an improvement in ammonia retention compared to the parent GO. Ammonia was retained on the surface via interactions with functional groups of GO or with the heteropolyacids. Seredych and Bandosz [50] prepared GO/aluminium-zirconium polycation composites for adsorption of ammonia. They found that pre-humidification could play an important role in adsorption. Water on the surface increased $\mathrm{NH}_{3}$ adsorption via acid-base reactions. Also, the surfactant used for dispersion affected the performance. More surfactant leads to a higher dispersion of graphene-like layers and intercalation of ammonia can occur. They also synthesized $\mathrm{GO} / \mathrm{MnO}_{2}$ composites for ammonia removal and found an enhanced adsorption capacity. In the composites, $\mathrm{Mn}(\mathrm{IV})$ acts as an oxidant for ammonia and GO functional groups contribute to oxygen activation. A low degree of GO oxidation leads to the deposition of the manganese oxide component at lower oxidation state, resulting in low adsorption [51].

For graphene composites, Petit et al. [52] tested a new water-stable composites based on a metal organic framework (MOF) and graphene. Ammonia adsorption capacities on the composites are higher than the ones from the physical mixture of components, due to a synergetic effect between the MOF and graphene layers. Moreover, more ammonia is adsorbed in moist conditions than in dry conditions owing to its dissolution in a water film present in the pore system.

For other toxic gases, Seredych et al. [53] tested zirconium-hydroxide/graphene composites for sulfur dioxide $\left(\mathrm{SO}_{2}\right)$ removal at ambient conditions. An enhanced adsorption of $\mathrm{SO}_{2}$ on the composites is linked to the formation of new basic sites and porosity developed by the interactions between zirconium hydroxide units and the oxygen groups attached to the graphene layers. Both physical adsorption and reactive adsorption of $\mathrm{SO}_{2}$ via formation of sulfites were responsible and the graphene could catalyze $\mathrm{SO}_{2}$ oxidation to form sulfates.

Petit et al. [54] reported GO/Cu-MOF composites for hydrogen sulfide $\left(\mathrm{H}_{2} \mathrm{~S}\right)$ removal. An enhancement in $\mathrm{H}_{2} \mathrm{~S}$ adsorption was attributed to physical adsorption of water and $\mathrm{H}_{2} \mathrm{~S}$ in the pore space formed at the interface between the MOF units and the graphene layers. Besides the physisorption, reactive adsorption was also found as the main mechanism. $\mathrm{H}_{2} \mathrm{~S}$ molecules bind to the copper centers of the MOF. Water enhances adsorption in the composites as it allows the dissolution of hydrogen sulphide. Mabayoje et al. [55] recently reported reactive adsorption of $\mathrm{H}_{2} \mathrm{~S}$ on $\mathrm{GO} /$ copper (hydr)oxides composites. $\mathrm{H}_{2} \mathrm{~S}$ was retained on the surface via a direct replacement of $\mathrm{OH}$ groups and via acid-base reactions with the copper (hydr)oxide by formation of sulfites and 
sulfates. Moreover, moisture in the $\mathrm{H}_{2} \mathrm{~S}$ stream has a positive effect on the removal process owing to the dissociation process.

Formaldehyde is one of VOCs as main indoor air pollutants, which comes from paint, decorating materials. Indoor VOCs can cause sick building syndrome and removal of VOCs can be achieved by adsorption and catalytic decomposition [56]. Matsuo et al. prepared several silylated GO composites using 3-aminopropylmethyldiethoxysilane, 3-aminopropylethoxysilanes and 3aminopropyltriethoxysilane for formaldehyde and butyraldehyde adsorption $[57,58]$. Due to the reaction of amino groups of silylating reagents introduced into the interlayer space of GO with aldehydes forming $\mathrm{C}=\mathrm{N}$ bonding, silylated $\mathrm{GO}$ adsorbed formaldehyde at $36.1-91.2 \mathrm{mg} / \mathrm{g}$, much higher than that on activated carbon, even when water molecules were preadsorbed.

Therefore, it is concluded that functional groups on layer-structured GO and GNs are responsible for adsorption of gases $\left(\mathrm{NH}_{3}, \mathrm{SO}_{2}, \mathrm{H}_{2} \mathrm{~S}\right)$. Introduction of metal centers into $\mathrm{GO}$ or GNs surface will promote reactive adsorption and water can also induce strong adsorption of those gases. The adsorption behavior is different from other carbons in which porosity plays an important role in adsorption.

4.

Water treatment by GO or GNs adsorption

There are many pollutants in groundwater, surface water and wastewater systems. The important pollutants in water include anions and heavy metal cations as well as organic compounds. For removal of those pollutants, various carbon materials including activated carbon [59-61] and carbon nanotubes $[13,62]$ have been widely investigated in previous years and they show high adsorption capacity. Compared with activated carbon and carbon nanotubes, GO and GNs also present strong adsorption for many water pollutants.

\subsection{Inorganic metal/metalloid cations.}

Heavy metals are the most important pollutants in water due to their strong toxicity to plants, animals and human beings. The most heavy metals in polluted waters include $\mathrm{Hg}, \mathrm{Pb}, \mathrm{Ag}, \mathrm{Cu}, \mathrm{Cd}$, $\mathrm{Cr}, \mathrm{Zn}, \mathrm{Ni}, \mathrm{Co}$ and $\mathrm{Mn}$. Most of metal ions are present in cation forms but some metals are in anions such as $\mathrm{Cr}(\mathrm{VI})$ with $\mathrm{CrO}_{4}{ }^{2-}, \mathrm{Cr}_{2} \mathrm{O}_{7}{ }^{2-}$ forms. In addition, $\mathrm{As}(\mathrm{V})$ with $\mathrm{H}_{2} \mathrm{AsO}_{4}{ }^{-}$and $\mathrm{HAsO}_{4}{ }^{2-}$ is important metalliod ion, strong toxic in water. Currently, adsorption is the most effective way to remove heavy metal ions because the metal ions can not be degraded by bioprocess and chemical reactions. Due to strong functional groups on GO surface, GO will be a potential adsorbent for metal ion complexation through both electrostatic and coordinate approaches. Table 1 summarizes adsorption capacities of metals and metalloids on GO, GNs and their composites. Generally, GO presents high adsorption capacity on cationic metals and GN can be used for adsorption of both 
cationic and anionic metals. After modification of GO with organics or metal oxides, GO composites can also be used for anionic metal removal due to functionalization.

Yang et al. [63] investigated $\mathrm{Cu}^{2+}-\mathrm{GO}$ interaction in aqueous solution and reported that $\mathrm{Cu}^{2+}$ causes GO sheets to be folded and also to form large aggregates. The coordination between $\mathrm{Cu}^{2+}$ and oxygen atoms on GO is the primary driving force and GO has a $\mathrm{Cu}^{2+}$ adsorption capacity of 46.6 $\mathrm{mg} / \mathrm{g}$, higher than that of carbon nanotubes $(28.5 \mathrm{mg} / \mathrm{g}$ ) and active carbon $(4-5 \mathrm{mg} / \mathrm{g})$. Zhao et al. synthesized few-layered GO nanosheets (GOS) and tested for the removal of $\mathrm{Cd}^{2+}$ [64], $\mathrm{Co}^{2+}$ [64], $\mathrm{Pb}^{2+}$ [65], and U(VI) [66] ions from aqueous solutions. They found that the abundant oxygencontaining functional groups on GO surfaces played an important role in metal sorption. $\mathrm{Cd}^{2+}$ and $\mathrm{Co}^{2+}$ sorption on GOS was strongly dependent on $\mathrm{pH}$ and weakly dependent on ionic strength. The presence of humic acid reduced $\mathrm{Cd}^{2+}$ and $\mathrm{Co}^{2+}$ sorption on $\mathrm{GOS}$ at $\mathrm{pH}<8$. The maximum sorption capacities of $\mathrm{Cd}^{2+}$ and $\mathrm{Co}^{2+}$ on $\mathrm{GOS}$ at $\mathrm{pH} 6.0$ and $30{ }^{\circ} \mathrm{C}$ were about 106.3 and $68.2 \mathrm{mg} / \mathrm{g}$, respectively. For $\mathrm{Pb}^{2+}$, the maximum adsorption capacities were about 842,1150 , and $1850 \mathrm{mg} / \mathrm{g}$ at 20,40 , and $60{ }^{\circ} \mathrm{C}$, respectively [65], but sorption capacity of U(VI) at $\mathrm{pH} 5.0,20{ }^{\circ} \mathrm{C}$ was $97.5 \mathrm{mg} / \mathrm{g}$ [66].

Modification of GO with organics can change the surface functional groups for better adsorption of various metal species. Gao et al. [67] prepared a modified GO with thiol groups by diazonium chemistry. The surface modified GO (GO-SH) adsorbed 6-fold higher concentration of $\mathrm{Hg}^{2+}$ ions than GO and activated carbon. Madadrang et al. [68] used N-(trimethoxysilylpropyl) ethylenediamine triacetic acid (EDTA-silane) to obtain a chelating GO for $\mathrm{Pb}^{2+}$ removal. The adsorption was fast and completed within $20 \mathrm{~min}$ and adsorption capacity was $479 \mathrm{mg} / \mathrm{g}$ at $\mathrm{pH} 6.8$.

Chitosan (CS) is a widely used bioadsorbent for the removal of metal ions. Modification of CS with GO can enhance the strength and the electrical conductivity of polymer composites. He et al. [69] prepared porous GO/chitosan materials (PGOC) for adsorption of metal ions. The incorporation of GO significantly increased the compressive strength of the PGOC materials. The adsorption capacity of $\mathrm{Pb}^{2+}$ was increased by $31 \%$ to $99 \mathrm{mg} / \mathrm{g}$ at $5 \mathrm{wt} \%$ GO. Zhang et al. [70] also reported ordered porous chitosan-gelatin/GO monoliths (CGGO) for $\mathrm{Cu}^{2+}$ and $\mathrm{Pb}^{2+}$ adsorption. The CGGO at $5 \mathrm{wt} \%$ GO exhibited an extremely high adsorbing ability for both metal ions and the CGGO can be recycled several times with only a slight loss in adsorption. Liu et al. [71] also prepared chitosan/GO composites (CSGO) for the adsorption of noble metals, $\mathrm{Au}^{3+}$ and $\mathrm{Pd}^{2+}$, in aqueous solution. Chitosan with $5 \mathrm{wt} \%$ GO (CSGO5) composite demonstrated the largest adsorption capacity for $\mathrm{Au}^{3+}(1077 \mathrm{mg} / \mathrm{g})$ and $\mathrm{Pd}^{2+}(217 \mathrm{mg} / \mathrm{g})$ and more importantly, CSGO5 can be used repeatedly.

GO and GNs can also be incorporated with metal oxides. A composite with GO and metal/oxide usually has specific features and has been used as effective adsorbents for removal of different 
pollutants. Lee and Yang [72] prepared a flower-like $\mathrm{TiO}_{2}$ on $\mathrm{GO}$ hybrid $\left(\mathrm{GO}-\mathrm{TiO}_{2}\right)$ and applied for the removal of $\mathrm{Zn}^{2+}, \mathrm{Cd}^{2+}$ and $\mathrm{Pb}^{2+}$ ions from water. The adsorption capacities of the $\mathrm{GO}-\mathrm{TiO}_{2}$ hybrid reached $88.9 \mathrm{mg} / \mathrm{g}$ for $\mathrm{Zn}^{2+}, 72.8 \mathrm{mg} / \mathrm{g}$ for $\mathrm{Cd}^{2+}$, and $65.6 \mathrm{mg} / \mathrm{g}$ for $\mathrm{Pb}^{2+}$, respectively, at $\mathrm{pH}$ 5.6, which are higher than either $\mathrm{GO}$ or $\mathrm{TiO}_{2}$.

Recently, magnetic adsorbents have attracted intensive interest in water treatment due to easy separation and collection using a magnet. Incorporation of magnetic particles with GO or GNs should offer an effective approach to overcome the separation problems associated with graphene. At the same time, loading of the magnetite nanoparticles can avoid or decrease the possibility of serious agglomeration and restacking of the graphene sheets, and consequently provide a higher available surface area and enhancement of adsorption capacity [73]. Liu et al. [74] reported a magnetite $\mathrm{Fe}_{3} \mathrm{O}_{4} / \mathrm{GO}$ composite $(\mathrm{M} / \mathrm{GO})$ for the removal of $\mathrm{Co}^{2+}$ from aqueous solutions and investigated adsorption kinetics, equilibrium and thermodynamics. M/GO was found to have higher adsorption than that on $\mathrm{Fe}_{3} \mathrm{O}_{4}$ and can be separated and recovered by magnetic separation after adsorption.

It is well known that adsorption strongly depends on the pore structure and surface area as well as surface functionality of adsorbents. Due to removal of functional groups in reduction process, GNs lose affinity to some metal ions. However, GNs have a high surface area, and can also be a good adsorbent. Unlike GO, adsorption on GNs mainly occurs on their planar surface via the van de Waals force. Machida et al. [75] investigated $\mathrm{Pb}^{2+}$ adsorption onto a graphene layer of activated carbon and charcoal and found that acidic oxygen sites from carboxylic and lactonic groups and basic sites from $\pi$ electrons on graphene layer would be responsible for the $\mathrm{Pb}^{2+}$ adsorption. Huang et al. [76] prepared GNs to adsorb $\mathrm{Pb}^{2+}$ ions from an aqueous system. Although the oxygen complexes of GNs showed a significant decrease, GNs still presented strong $\mathrm{Pb}^{2+}$ adsorption and heat treatment could increase the adsorption due to the Lewis basicity.

Deng et al. [77] employed electrolysis to fabricate two functionalized GNs, GNs ${ }^{\mathrm{PF} 6}$ with potassium hexafluorophosphate solution and $\mathrm{GNs}^{\mathrm{C} 8 \mathrm{P}}$ with 1-octyl-3-methyl-imidazolium hexafluorophosphate, respectively. The GNs ${ }^{\mathrm{PF} 6}$ and $\mathrm{GNs}^{\mathrm{C} 8 \mathrm{P}}$ were tested for the removal of $\mathrm{Pb}^{2+}$ or $\mathrm{Cd}^{2+}$ ions from water. The adsorption capacities of $\mathrm{GNs}{ }^{\mathrm{PF} 6}$ are $406.6 \mathrm{mg} / \mathrm{g}(\mathrm{pH}=5.1)$ for $\mathrm{Pb}^{2+}$ and $73.42 \mathrm{mg} / \mathrm{g}(\mathrm{pH}=6.2)$ for $\mathrm{Cd}^{2+}$, much higher than that $\mathrm{GNs}^{\mathrm{C} 8 \mathrm{P}}$ and carbon nanotubes. Later Hao et al. [78] prepared a $\mathrm{SiO}_{2} /$ graphene composite and tested it for $\mathrm{Pb}^{2+}$ adsorption. The composite shows high efficiency and high selectivity toward $\mathrm{Pb}^{2+}$ ion. The maximum adsorption capacity of the composite for $\mathrm{Pb}^{2+}$ ion was $113.6 \mathrm{mg} / \mathrm{g}$, much higher than that of bare $\mathrm{SiO}_{2}$ nanoparticles. It is believed that electrostatic interaction between $\mathrm{Pb}^{2+}$ cations and negative surface charge and/or $\pi$ electrons of the composite is the main interaction for the adsorption of $\mathrm{Pb}^{2+}$ ion onto the composite. 
Chandra and Kim [79] reported the synthesis of the polypyrrole-reduced graphene oxide composite (PPy-RGO), which shows a highly selective $\mathrm{Hg}^{2+}$ removal capacity. The adsorption capacity of $\mathrm{Hg}^{2+}$ is $980 \mathrm{mg} / \mathrm{g}$. Sreeprasad et al. [80] then reported some reduced GO (RGO)-metal/metal oxide composites for water purification. $\mathrm{MnO}_{2}-\mathrm{RGO}$ and $\mathrm{Ag}-\mathrm{RGO}$ demonstrated higher $\mathrm{Hg}^{2+}$ adsorption than GO and RGO. Ren et al. [81] synthesized a $\mathrm{GNs} / \delta-\mathrm{MnO}_{2}$ composite $\left(\mathrm{GNs} / \mathrm{MnO}_{2}\right)$ by a microwave-assisted method for $\mathrm{Ni}^{2+}$ removal from solution. The adsorption capacity of $\mathrm{Ni}^{2+}$ onto $\mathrm{GNs} / \mathrm{MnO}_{2}$ is $46.6 \mathrm{mg} / \mathrm{g}$ at room temperature, which is 1.5 and 15 times higher than those of pure $\delta-\mathrm{MnO}_{2}$ and $\mathrm{GNs}$, respectively. Also $\mathrm{GNs} / \mathrm{MnO}_{2}$ can be reused for 5 times with high recovery rate of $91 \%$.

Arsenic is one of the most toxic elements and is usually present in ground water. Mishra and Ramaprabhu [82] synthesized GNs by hydrogen induced exfoliation of GO followed by functionalization for simultaneous removal of high concentration of arsenic (As(III) and As(V)) and sodium from aqueous solution. The maximum adsorption capacities for arsenate, arsenite and sodium were found to be nearly 142, 139 and $122 \mathrm{mg} / \mathrm{g}$, respectively. Chandra et al. [83] synthesized magnetite-graphene hybrids (M-RGO) for As(III) and As(V) adsorption. They investigated the adsorption performance at various conditions and found the composites showed near complete (over 99.9\%) arsenic removal within 1 ppb. Zhang et al. [84] synthesized GO crosslinked with ferric hydroxide (GO-Fe) and tested for arsenate removal from contaminated drinking water. The composite GO-Fe-5 showed an adsorption capacity of $23.8 \mathrm{mg}$ arsenate/g-composite. Effective arsenate removal could be achieved in a wide range of $\mathrm{pH} 4-9$. $\mathrm{Wu}$ et al. [85] also fabricated a composite material (MGL), containing magnetite particles, GNs and layered double hydroxides (LDHs), to remove arsenate from aqueous solutions. The surface area of the MGL is greatly enhanced through the incorporation of magnetite particles and GNs, which provides more active sites for arsenate uptake. The adsorption capacities are $37.73 \mathrm{mg} / \mathrm{g}$ for LDHs and $73.14 \mathrm{mg} / \mathrm{g}$ for MGL.

Similar to arsenic, chromium is another important metal pollutant in water either in $\mathrm{Cr}$ (III) or $\mathrm{Cr}(\mathrm{VI})$. $\mathrm{Cr}(\mathrm{VI})$ is more toxic than $\mathrm{Cr}(\mathrm{III})$. Ma et al. [86] prepared ethylenediamine-reduced GO (ED-RGO) sheets for effective removal of $\mathrm{Cr}(\mathrm{VI})$. They found that $\mathrm{Cr}(\mathrm{VI})$ was removed from aqueous solution through an indirect reduction mechanism with the aid of $\pi$ electrons on the carbocyclic six-membered ring of ED-RGO, and part of $\mathrm{Cr}$ (III) species were bound to the surface of ED-RGO (Fig.3). Jabeen et al. [87] synthesized nanoscale iron decorated GNs via sodium borohydride reduction of GO. The material showed enhanced magnetic property, surface area and $\mathrm{Cr}(\mathrm{VI})$ adsorption capacity compared to bare iron nanoparticles. Zhu et al. [88] also reported a magnetic graphene nanocomposites (MGNCs) with a core@double-shell structure. The MGNCs demonstrated an extremely fast $\mathrm{Cr}(\mathrm{VI})$ removal from the wastewater with a high removal efficiency 
and complete removal of $\mathrm{Cr}(\mathrm{VI})$ within $5 \mathrm{~min}$ at the conditions of $[\mathrm{MGNCs}]=1 \mathrm{~g} / \mathrm{L},[\mathrm{Cr}(\mathrm{VI})]=$ $1000 \mu \mathrm{g} / \mathrm{L}, \mathrm{pH} 7$.

Fig.3 Proposed mechanism of Cr(VI) removal by ED-RGO.

\section{Table 1}

\subsection{Inorganic anions.}

Unlike heavy metal ions, which can induce significant toxicity, some inorganic anions, $\mathrm{F}, \mathrm{NO}_{3}{ }^{-}$, $\mathrm{SO}_{4}{ }^{2-}, \mathrm{ClO}_{4}{ }^{-}, \mathrm{PO}_{4}{ }^{3-}$, are also present in water. These anions in large quantities can induce water contamination and should be removed. For example, the presence of large quantities of nitrate and phosphate in water will cause eutrophication. Due to negative charge of anions, GO is not effective for the adsorption. Only a few investigations have been reported on their adsorptive removal by GNs and functionalized systems. Li [89] tested the adsorption of fluoride from aqueous solution by graphene and reported that graphene was an excellent fluoride adsorbent with an adsorption capacity of $35.6 \mathrm{mg} / \mathrm{g}$ at $\mathrm{pH}=7.0,25^{\circ} \mathrm{C}$. Fluoride ions are predominantly adsorbed by the surfaceexchange between fluoride ions in solution and hydroxyl ions on the adsorbent. Zhang et al. [90] reported a 3D nanostructured graphene-polypyrrole (Ppy) nanocomposite for perchlorate $\left(\mathrm{ClO}_{4}^{-}\right)$ purification. The graphene-Ppy nanocomposite exhibited a significantly improved uptake capacity for $\mathrm{ClO}_{4}{ }^{-}$compared with Ppy film alone and can be used for $\mathrm{ClO}_{4}{ }^{-}$removal through an electrically switched ion exchange. Vasudevan and Lakshmi [91] recently reported a systematic study of phosphate adsorption on graphene in aqueous solution and found that graphene is an excellent phosphate adsorbent with an adsorption capacity of up to $89.4 \mathrm{mg} / \mathrm{g}$.

\subsection{Organic dyes.}

Dyes are important water pollutants, which are discharged from many sources such as printing, textile, dyeing, paper and pulp, tannery and paint industries. Most of dyes have a complex molecular structure and are more stable and difficult to be biodegraded. The presence of dyes in water can cause problem to aquatic life and some dyes are toxic to human life. In water, most of dyes are dissolved and present in either catonic or anionic ions. Few are dispersive dyes. For dye adsorption, GO, GNs and their composites with metal, metal oxide and chitosan were tested. Table 2 presents some dye adsorption capacities on various GO, GNs and their composites. Due to ionic forms of dye molecules in water, major interaction attributed to dye adsorption on GO and GNs is cationic-anionic force. GO exhibits high adsorption of cationic dyes, but low affinity for anionic dyes, due to the strong electrostatic repulsion between GO and dyes. GNs and composites can be good adsorbents for cationic and anionic dyes attributed to $\pi-\pi$ stacking. 
Bradder et al. [92] first tested GO for the removal of cationic dyes, methylene blue (MB) and malachite green (MG), in aqueous solution. The adsorption capacities of MB and MG on the GO were 351 and $248 \mathrm{mg} / \mathrm{g}$, respectively, much higher than those on graphite and activated carbon. The adsorption mechanism was proposed as electrostatic attraction. Other researchers also found that GO was a highly effective absorbent for MB giving adsorption capacity of $714 \mathrm{mg} / \mathrm{g}$ [93] and 1939 $\mathrm{mg} / \mathrm{g}$ [94]. The adsorption was more efficient at lower temperatures and higher $\mathrm{pH}$ values. The ionic strength and dissolved organic matter would enhance the MB removal process. Liu et al. synthesized a 3D graphene oxide sponge (GO sponge) and tested for removal of cationic dyes, MB and methyl violet (MV). The 3D-GO sponge demonstrated adsorption capacities of 397 and 467 $\mathrm{mg} / \mathrm{g}$ for MB and MV, respectively. The activation energies of adsorption through the strong $\pi-\pi$ stacking and anion-cation interaction were obtained at 50.3 and $70.9 \mathrm{~kJ} / \mathrm{mol}$, respectively.[95]

Liu et al. [96] tested GNs for adsorption of MB and obtained the maximum adsorption capacity of $153.8 \mathrm{mg} / \mathrm{g}$ at $20^{\circ} \mathrm{C}$. The effect factors including $\mathrm{pH}$, contact time, temperature and dosage on the adsorption properties of MB onto GNs were also investigated. Li et al. [97] reported GNs for removal of cationic red X-GRL from aqueous solutions and influence of $\mathrm{pH}$, adsorbent dosage, contact time, and temperature on adsorption behaviour. The maximum monolayer adsorption capacity of $317 \mathrm{mg} / \mathrm{g}$ at $15^{\circ} \mathrm{C}$ was obtained. Sun et al. [98] found that in situ reduction of GO with sodium hydrosulfite to graphene can enhance adsorption capability of a cationic dye, acridine orange (AO). Under identical conditions, GO showed a maximum adsorption capacity of $1.4 \mathrm{~g} / \mathrm{g}$, and reduced GO provided a maximum adsorption capacity of $3.3 \mathrm{~g} / \mathrm{g}$, due to the conversion of carbonyl groups on GO into hydroxyl groups.

Ramesha et al. [99] compared GO and GNs for the adsorption of cationic dyes, MB, MV, rhodamine $B(\mathrm{RB})$, and an anionic dye, orange $\mathrm{G}(\mathrm{OG})$ from aqueous solutions. It was found that GO due to the large negative charge density was effective for adsorption of cationic dyes, but negligible for anionic dyes. On the other hand, graphene was found to be a very good adsorbent for anionic dyes. Raman and FT-IR show that electrostatic interactions play a role with GO/MV and GO/MB while it is only the van der Waals interaction with GO/OG. The interactions with GO/RB are probably both electrostatic and van der Waals type.

Apart from GO and GNs, various composites composed of GO and GNs were also synthesized and tested for different dye adsorption. Sui et al. [100] reported fabrication of a carbon nanotube (MWCNT)-graphene hybrid aerogel. The resulting hybrid aerogels showed very promising performance in water purification including capacitive deionization of light metal salts, removal of organic dyes and enrichment of heavy metal ions. Adsorption capacities of Graphene/c-MWCNT composite are 150.2, 191.0, 180.8, and $35.8 \mathrm{mg} / \mathrm{g}$ for RB, MB, Fuchsine and acid fuchsine, respectively. Cheng et al. [101] prepared a hydrophilic and biocompatible three-dimensional (3D) 
chitosan-graphene mesostructures and tested for removal of reactive black 5 (RB5) from aqueous solution. A removal efficiency of $97.5 \%$ can be achieved readily at initial RB5 concentrations of 1.0 $\mathrm{mg} / \mathrm{mL}$.

Nguyen-Phan et al. [102] fabricated a reduced graphene oxide-titanate (RGO-Ti) hybrids with larger surface areas and higher pore volumes. The dye uptake (MB) reached the maximum value $(83.3 \mathrm{mg} / \mathrm{g})$ over the hybrid, higher than those obtained on pure GNs $(48.7 \mathrm{mg} / \mathrm{g})$ and tubular titanates $(36.5 \mathrm{mg} / \mathrm{g})$. Li et al. reported the synthesis of $\mathrm{Cu}_{2} \mathrm{O}$-graphene [103] and $\mathrm{Mg}(\mathrm{OH})_{2^{-}}$ graphene [104] and adsorption of dyes, MB and RB. Both composites exhibited excellent behavior for dye removal.

Similar to metal ion adsorption, several types of magnetic GO or GN composites using $\mathrm{Fe}^{0}, \mathrm{Fe}_{3} \mathrm{O}_{4}$, and $\mathrm{MFe}_{2} \mathrm{O}_{4}(\mathrm{M}=\mathrm{Mn}, \mathrm{Zn}$, Co and $\mathrm{Ni})$, were also reported for dye adsorption due to magnetic separation. Xie et al. [105] prepared a superparamagnetic $\mathrm{GO}-\mathrm{Fe}_{3} \mathrm{O}_{4}$ composite $\left(\mathrm{GO}-\mathrm{Fe}_{3} \mathrm{O}_{4}\right)$ and tested in adsorption of dyes, $\mathrm{MB}$ and neutral red (NR). It was found that $\mathrm{GO}-\mathrm{Fe}_{3} \mathrm{O}_{4}$ only took 30 min for MB and 90 min for NR to attain equilibrium. The adsorption capacities for MB and NR are 167.2 and $171.3 \mathrm{mg} / \mathrm{g}$, respectively. Ai et al. [106] employed a one-step solvothermal method to obtain a GNs/magnetite $\left(\mathrm{Fe}_{3} \mathrm{O}_{4}\right)$ composite. The resulting $\mathrm{GNs} / \mathrm{Fe}_{3} \mathrm{O}_{4}$ composite showed extraordinary adsorption capacity and fast adsorption rates for removal of MB. Geng et al. [107] synthesized a functional hybrid of reduced graphene oxide $\mathrm{RGO}-\mathrm{Fe}_{3} \mathrm{O}_{4}$ nanoparticles. The hybrid possesses quite a good and versatile adsorption capacity to different dyes, RB, Rhodamine $6 \mathrm{G}$ (R6G), acid blue 92 (AB92), orange (II) (OII), MG and new coccine (NC) as shown in Fig.4.

Fig.4 The saturated adsorption capacity $(Q)$ values for all of these dyes using RGF-1 (black), RGF2 (red), and RGF-3 (blue) as the adsorbents. RGF-1, RGF-2 and RGF-3 are referred to composites at $\mathrm{C} / \mathrm{Fe}$ atomic ratios of 1.7:1, 3.0:1 and 7.0:1, respectively.

Sun et al. [73] prepared magnetite $\mathrm{Fe}_{3} \mathrm{O}_{4} /$ reduced graphene oxide $\left(\mathrm{Fe}_{3} \mathrm{O}_{4}-\mathrm{RGO}\right)$ nanocomposites for removal of dye pollutants, $\mathrm{MB}$ and MG. These $\mathrm{Fe}_{3} \mathrm{O}_{4}$ - $\mathrm{RGO}$ nanocomposites exhibited excellent removal efficiency (>90\%) in synthetic dye water and real industrial waste water and lake water. Wang et al. [108] synthesized a magnetic $\mathrm{Fe}_{3} \mathrm{O}_{4}$ /graphene nanocomposite for the removal of a dye fuchsine from aqueous solutions. The adsorption capacity of the $\mathrm{Fe}_{3} \mathrm{O}_{4} / \mathrm{GNs}$ for fuchsine did not show any significant decrease even after five regenerations. Yao et al. [109] reported the synthesis of magnetic $\mathrm{Fe}_{3} \mathrm{O}_{4}$ /graphene composite (FGC) and utilization in dye removal from aqueous media. Adsorption isotherm and kinetics of MB and Congo red (CR) onto FGC were studied in a batch system. The maximum adsorption capacities of MB and CR on FGC were found to be 45.3 and 33.7 $\mathrm{mg} / \mathrm{g}$, respectively. 
$\mathrm{Li}$ et al. [110] synthesized magnetic $\mathrm{CoFe}_{2} \mathrm{O}_{4}$-functionalized graphene sheets $\left(\mathrm{CoFe}_{2} \mathrm{O}_{4}-\mathrm{GNs}\right)$ nanocomposites for adsorption of methyl orange (MO) from aqueous solution, which showed adsorption capacity as high as $71.5 \mathrm{mg} / \mathrm{g}$. Bai et al. [111] developed a one-pot solvothermal synthesis method to prepare reduced graphene oxide (RGO) supported ferrite $\left(\mathrm{MFe}_{2} \mathrm{O}_{4}, \mathrm{M}=\mathrm{Mn}\right.$, $\mathrm{Zn}$, Co and $\mathrm{Ni}$ ) hybrids. The obtained hybrids are effective adsorbents for removal of dye pollutants. It was found that over $92 \%$ rhodamine B (RB) and $100 \%$ methylene blue (MB) with a concentration of $5 \mathrm{mg} / \mathrm{L}$ could be removed by the hybrids within $2 \mathrm{~min}$ when the concentration of the hybrids was $0.6 \mathrm{~g} / \mathrm{L}$. In addition, the hybrids also showed enhanced photocatalytic activity in the degradation of $\mathrm{RB}$ and $\mathrm{MB}$. Yao et al. [112] synthesized amino-functionalized $\mathrm{Fe}_{3} \mathrm{O}_{4} / \mathrm{SiO}_{2}$ core/shell nanoparticles and incorporated with $\mathrm{GO}$ to form $\mathrm{Fe}_{3} \mathrm{O}_{4} / \mathrm{SiO}_{2}-\mathrm{GO}$ nanoparticles. Adsorption equilibrium and kinetics of $\mathrm{MB}$ on the $\mathrm{Fe}_{3} \mathrm{O}_{4} / \mathrm{SiO}_{2}-\mathrm{GO}$ were studied in a batch system. The maximum adsorption capacities were found to be $97.0,102.6,111.1 \mathrm{mg} / \mathrm{g}$ at 25,45 , and $60{ }^{\circ} \mathrm{C}$, respectively.

Guo et al. [113] synthesized $\mathrm{Fe}^{0}$-graphene composites (FGC) for decolorization of methyl blue solution. Fan et al. reported a magnetic chitosan and GO system (MCGO) for adsorption of cotton blue (CB) [114] and MB [115]. The effect factors including $\mathrm{pH}$, contact time and temperature on the adsorption properties of methylene blue onto MCGO were investigated. Moreover, the MCGO was stable and easily recoverable. The adsorption capacity was about $90 \%$ of the initial saturation adsorption capacity after being used four times.

Table 2

\subsection{Other organic pollutants.}

Natural organic matters and a large of persistent aromatic pollutants are widely present in different surface water and wastewaters from pharmaceuticals, pesticides and other industries. Their high solubility in water makes them easily to transport into the environment and are highly toxic to human health. Some investigations have been conducted in using GO and GNs for adsorption of humic acids, phenolic compounds, pesticides and drugs. In general, five possible interactions including hydrophobic effect, $\pi-\pi$ bonds, hydrogen bonds, and covalent and electrostatic interactions have been observed in carbon materials and believed to be responsible for the adsorption of organic chemicals on the surface of carbon nanosized particles [116]. For GO and GNs, most investigations found that $\pi-\pi$ interaction plays the important role in adsorption.

Hartono et al. [117] first reported the application of GO for humic acid (HA) adsorption in aqueous solution. They found that the GO exhibited strong and much higher adsorption capacity of HA than graphite. The maximum adsorption capacity of the GO from the Langmuir isotherm was $190 \mathrm{mg} / \mathrm{g}$, 
higher than activated carbon. Gao et al. [118] reported the adsorption of some antibiotics, tetracycline, oxytetracycline and doxycycline, on GO. The maximum adsorption capacities from the Langmuir model were 313, 212 and $398 \mathrm{mg} / \mathrm{g}$ for tetracycline, oxytetracycline and doxycycline, respectively. The adsorption capacities decreased with the increase in $\mathrm{pH}$ or $\mathrm{Na}^{+}$concentration. The mechanism of adsorption was attributed to $\pi-\pi$ interaction and cation- $\pi$ bonding.

Wu et al. [119] evaluated GNs for the adsorption of acrylonitrile (AN), p-toluenesulfonic acid (pTA), 1-naphthalenesulfonic acid (1-NA) and methyl blue. The results showed that the organic chemicals with larger molecule size and more benzene rings possessed a higher adsorption speed and a higher maximum adsorption capacity on GNs. The maximum adsorption capacities of p-TA, 1-NA and methyl blue on GNs are 1430, 1460 and $1520 \mathrm{mg} / \mathrm{g}$ at $30^{\circ} \mathrm{C}$, respectively. The efficiency remained almost constant during a five-cycle adsorption-desorption process. Li et al. [120] also used GNs as an adsorbent to remove phenol from aqueous solution and investigated the effects of $\mathrm{pH}$, dosage, contact time, and temperature on phenol adsorption. The maximum adsorption capacity can reach $28.26 \mathrm{mg} / \mathrm{g}$ at the conditions of initial phenol concentration of $50 \mathrm{mg} / \mathrm{L}, \mathrm{pH} 6.3$ and 12 ${ }^{\circ} \mathrm{C}$. Recently, $\mathrm{Xu}$ et al. [121] investigated the adsorption of bisphenol A (BPA) from aqueous solution on GNs under different experimental conditions such as contact time, BPA concentration, temperature, $\mathrm{pH}$, and ionic strength. The adsorption capacity for BPA at $29^{\circ} \mathrm{C}$ was found to be 182 $\mathrm{mg} / \mathrm{g}$, higher than other carbonaceous adsorbents. The presence of $\mathrm{NaCl}$ in the solution could facilitate the adsorption process, whereas alkaline $\mathrm{pH}$ range and higher temperature of the solution were unfavorable. The $\pi-\pi$ interaction, hydrogen bonds, and $\mathrm{sp}^{2}$-hybridized single-atom-layer structure favored the adsorption of BPA on GNs.

Very recently, Pei et al. [122] investigated adsorption characteristics of 1,2,4-trichlorobenzene (TCB), 2,4,6-trichlorophenol (TCP), 2-naphthol and naphthalene (NAPH) on GO and GNs. Adsorption tests indicated the hydrophobic interaction and other specific interactions were involved in adsorption. TCB, TCP and 2-naphthol were adsorbed on GNs mainly via $\pi-\pi$ interaction while adsorption of TCP and 2-naphthol on GO was attributed to the formation of H-bonding between hydroxyl groups of TCP and 2-naphthol and O-containing functional groups on GO. Maliyekkal et al. [123] reported unprecedented adsorption of some pesticides, chlorpyrifos (CP), endosulfan (ES), and malathion (ML), onto GO and GNs from water. GNs showed high adsorption than GO and the adsorption capacities of CP, ES, and ML were as high as 1200, 1100, and $800 \mathrm{mg} / \mathrm{g}$, respectively. Density functional analysis showed that adsorption is mediated through water, while direct interactions between GNs and the pesticides are rather weak or unlikely. They also reported the synthesis of a sand-graphene composite using sugar as a graphene precursor and tested the adsorption in rhodamine 6G (R6G) and CP. Batch experiments showed adsorption capacities of 55 $\mathrm{mg} / \mathrm{g}$ for R6G and $48 \mathrm{mg} / \mathrm{g}$ for CP, which are superior to that of activated carbon[124]. 
In addition, various composites with different functionalities were also tested for adsorption of other different chemicals. Hu et al. [125] prepared a polydispersed and stable RNA-GO nanosheets to adsorb trace peptide toxin (microcystin-LR) in drinking water. The adsorption capacity of RNAGO nanosheets decreased at extreme $\mathrm{pH}$, temperature, ionic strength and natural organic matter, but it was suitable to adsorb trace pollutants in contaminated drinking water. Compared with other chemical and biological sorbents, RNA-GO nanosheets presented specific and competitive adsorption, and were easily synthesized and regenerated. Zhao et al. [126, 127] prepared sulfonated GNs with high dispersion properties in aqueous solution to adsorb naphthalene and 1-naphthol aromatic pollutants. The adsorption capability of the prepared sulfonated graphene nanomaterials

approaches $\sim 2.3-2.4 \mathrm{mmol} / \mathrm{g}$ for naphthalene and 1-naphthol, higher than activated carbon, ordered

mesoporous silica, natural bentonite and multiwalled carbon nanotubes. They suggested strong $\pi-\pi$ interaction between graphene sheets and the aromatic organic molecules contributed to the high adsorption.

$\mathrm{Wu}$ et al. [128] tested a magnetic graphene nanocomposite for the preconcentration of five carbamate pesticides (metolcarb, carbofuran, pirimicarb, isoprocarb and diethofencarb). Under the optimum conditions, the enrichment factors were about 474 - 868, higher than the dispersive liquidliquid microextraction and the ultrasound-assisted surfactant-enhanced emulsification microextraction. Li et al. [129] also fabricated a magnetic Ni nanoparticles functionalized watersoluble graphene nanocomposites $\left(\mathrm{Ni} @ \mathrm{GSs}-\mathrm{C}\left(\mathrm{CH}_{3}\right)_{2} \mathrm{COONa}\right)$ and used it for removing aromatic compounds from wastewater. The $\mathrm{Ni} @ \mathrm{GSs}-\mathrm{C}\left(\mathrm{CH}_{3}\right)_{2} \mathrm{COONa}$ nanocomposites showed rapid adsorption rate, high capacity for benzene, toluene and dimethylbenzene, convenient magnetic separation and re-use.

\section{Conclusion and perspectives}

GO and GNs are new carbonaceous materials with high surface area and functional groups. These materials can be used as adsorbents to effectively remove various gaseous and aqueous pollutants. The adsorption depends on adsorbate forms, ionic or hydrophobic. As GO shows strong acidity and negative charges, it exhibits high adsorption of basic chemicals such as ammonia and cationic ions via reactive adsorption and ionic binding. On the contrary, due to loss of oxygen species, the $\pi-\pi$ interaction between GNs and the adsorbate plays a dominant role for adsorption on GNs. In addition, GO and GNs tend to aggregate in a layer-by-layer mode due to strong interplanar 
interaction, GO and GNs can be functionalized with metal/oxide and organics to form composites, which will improve the adsorption capacity. Magnetic GO/GNs nanocomposites demonstrate advantages in convenient magnetic separation and re-use of the adsorbents.

In order to be applicable toward high adsorption, the material should possess high porosity and high surface area. However, GO and GNs synthesized always have low surface areas. Physical and chemical activation is well-known for developing highly porous carbons from different carbon precursors. Recently, highly porous graphene through chemical activation of exfoliated GO precursors with $\mathrm{KOH}$ has been reported [130, 131], which can produce graphene with surface area over $3000 \mathrm{~m}^{2} / \mathrm{g}$. Peng et al. recently reported $\mathrm{CO}_{2}$ activation of GO to obtained GNs for phenol and MB adsorption[132]. However, few investigations have been attempted in GO/GNs activation and efforts should be made in the future in this area.

Previously, many different methods have been employed for reduction of GO to form GNs, however, the GNs show varying extents of oxygen species. The presence of oxygen species significantly affects the adsorption behavior of various pollutants on GNs and the results from different laboratories vary. Therefore, it is important to investigate the relationship between oxygen species of GO and GNs and their capacities.

\section{Acknowledgement}

This project is partially supported by the Australian Research Council under project no. DP130101319.

\section{References}

[1] J.N. Armor, Environmental Catalysis, Applied Catalysis B-Environmental, 1 (1992) 221-256.

[2] P. Biswas, C.Y. Wu, Control of toxic metal emissions from combustors using sorbents: A review, Journal of the Air \& Waste Management Association, 48 (1998) 113-127.

[3] M.S. El-Geundi, Adsorbents for industrial pollution control, Adsorption Science \& Technology, 15 (1997) 777-787.

[4] C. Kennes, E.R. Rene, M.C. Veiga, Bioprocesses for air pollution control, Journal of Chemical Technology and Biotechnology, 84 (2009) 1419-1436.

[5] M.C. Delhomenie, M. Heitz, Biofiltration of air: A review, Critical Reviews in Biotechnology, 25 (2005) 53-72.

[6] G.M. Gadd, Biosorption: critical review of scientific rationale, environmental importance and significance for pollution treatment, Journal of Chemical Technology and Biotechnology, 84 (2009) 13-28.

[7] S.P. Dubey, K. Gopal, J.L. Bersillon, Utility of adsorbents in the purification of drinking water: A review of characterization, efficiency and safety evaluation of various adsorbents, Journal of Environmental Biology, 30 (2009) 327-332.

[8] S. Wang, Y. Peng, Natural zeolites as effective adsorbents in water and wastewater treatment, Chemical Engineering Journal, 156 (2010) 11-24. 
[9] W.S.W. Ngah, L.C. Teong, M.A.K.M. Hanafiah, Adsorption of dyes and heavy metal ions by chitosan composites: A review, Carbohydrate Polymers, 83 (2011) 1446-1456.

[10] S. Sen Gupta, K.G. Bhattacharyya, Adsorption of heavy metals on kaolinite and montmorillonite: a review, Physical Chemistry Chemical Physics, 14 (2012) 6698-6723.

[11] A.A. Adeyemo, I.O. Adeoye, O.S. Bello, Metal organic frameworks as adsorbents for dye adsorption: overview, prospects and future challenges, Toxicological and Environmental Chemistry, 94 (2012) 1846-1863.

[12] Y. Kim, J. Yi, Advances in environmental technologies via the application of mesoporous materials, Journal of Industrial and Engineering Chemistry, 10 (2004) 41-51.

[13] X. Ren, C. Chen, M. Nagatsu, X. Wang, Carbon nanotubes as adsorbents in environmental pollution management: A review, Chemical Engineering Journal, 170 (2011) 395-410.

[14] G.P. Rao, C. Lu, F. Su, Sorption of divalent metal ions from aqueous solution by carbon nanotubes: A review, Separation and Purification Technology, 58 (2007) 224-231.

[15] M.B. Seymour, C.M. Su, Y. Gao, Y.F. Lu, Y.S. Li, Characterization of carbon nano-onions for heavy metal ion remediation, J. Nanopart. Res., 14 (2012).

[16] S. Wang, C.W. Ng, W. Wang, Q. Li, L. Li, A Comparative study on the adsorption of acid and reactive dyes on multiwall carbon nanotubes in single and binary dye systems, Journal of Chemical and Engineering Data, 57 (2012) 1563-1569.

[17] Y. Zhu, S. Murali, W. Cai, X. Li, J.W. Suk, J.R. Potts, R.S. Ruoff, Graphene and graphene oxide: synthesis, properties, and applications, Advanced Materials, 22 (2010) 3906-3924.

[18] X. Huang, Z. Yin, S. Wu, X. Qi, Q. He, Q. Zhang, Q. Yan, F. Boey, H. Zhang, Graphene-based materials: synthesis, characterization, properties, and applications, Small, 7 (2011) 18761902.

[19] Y. Liu, X. Dong, P. Chen, Biological and chemical sensors based on graphene materials, Chemical Society Reviews, 41 (2012) 2283-2307.

[20] B.F. Machado, P. Serp, Graphene-based materials for catalysis, Catalysis Science \& Technology, 2 (2012) 54-75.

[21] J. Yao, Y. Sun, M. Yang, Y. Duan, Chemistry, physics and biology of graphene-based nanomaterials: new horizons for sensing, imaging and medicine, Journal of Materials Chemistry, 22 (2012) 14313-14329.

[22] K. Lu, G. Zhao, X. Wang, A brief review of graphene-based material synthesis and its application in environmental pollution management, Chinese Science Bulletin, 57 (2012) 1223-1234.

[23] B.C. Brodie, On the atomic weight of graphite Philos. Trans. R. Soc. London 149 (1859) 249259.

[24] L. Staudenmaier, Verfahren zur darstellung der graphitsäure, Ber Deutsche Chem. Ges., 31 (1898) 1481-1487.

[25] W.S. Hummers, R.E. Offeman, Preparation of graphitic oxide, J. Am. Chem. Soc., 80 (1958) 1339.

[26] J.I. Paredes, S. Villar-Rodil, A. Martínez-Alonso, J.M.D. Tascón, Graphene Oxide Dispersions in Organic Solvents, Langmuir, 24 (2008) 10560-10564.

[27] X. Cui, C. Zhang, R. Hao, Y. Hou, Liquid-phase exfoliation, functionalization and applications of graphene, Nanoscale, 3 (2011) 2118-2126.

[28] J. Cao, G.-Q. Qi, K. Ke, Y. Luo, W. Yang, B.-H. Xie, M.-B. Yang, Effect of temperature and time on the exfoliation and de-oxygenation of graphite oxide by thermal reduction, $\mathrm{J}$ Mater Sci, 47 (2012) 5097-5105.

[29] L. Zhang, X. Li, Y. Huang, Y. Ma, X. Wan, Y. Chen, Controlled synthesis of few-layered graphene sheets on a large scale using chemical exfoliation, Carbon, 48 (2010) 2367-2371.

[30] M. Cardinali, L. Valentini, P. Fabbri, J.M. Kenny, Radiofrequency plasma assisted exfoliation and reduction of large-area graphene oxide platelets produced by a mechanical transfer process, Chemical Physics Letters, 508 (2011) 285-288. 
[31] Y. Zhu, S. Murali, M.D. Stoller, A. Velamakanni, R.D. Piner, R.S. Ruoff, Microwave assisted exfoliation and reduction of graphite oxide for ultracapacitors, Carbon, 48 (2010) 2118-2122.

[32] T. Szabo, O. Berkesi, I. Dekany, DRIFT study of deuterium-exchanged graphite oxide, Carbon, 43 (2005) 3186-3189.

[33] T. Szabo, O. Berkesi, P. Forgo, K. Josepovits, Y. Sanakis, D. Petridis, I. Dekany, Evolution of surface functional groups in a series of progressively oxidized graphite oxides, Chemistry of Materials, 18 (2006) 2740-2749.

[34] D.C. Luo, G.X. Zhang, J.F. Liu, X.M. Sun, Evaluation criteria for reduced graphene oxide, Journal of Physical Chemistry C, 115 (2011) 11327-11335.

[35] S. Guo, S. Dong, Graphene nanosheet: synthesis, molecular engineering, thin film, hybrids, and energy and analytical applications, Chemical Society Reviews, 40 (2011) 2644-2672.

[36] H. Sun, S. Liu, G. Zhou, H.M. Ang, M.O. Tadé, S. Wang, Reduced graphene oxide for catalytic oxidation of aqueous organic pollutants, ACS Applied Materials \& Interfaces, 4 (2012) 5466-5471.

[37] M.A. Gomez-Garcia, V. Pitchon, A. Kiennemann, Pollution by nitrogen oxides: an approach to $\mathrm{NO}_{\mathrm{x}}$ abatement by using sorbing catalytic materials, Environment International, 31 (2005) 445-467.

[38] K.-J. Kim, H.-G. Ahn, The effect of pore structure of zeolite on the adsorption of VOCs and their desorption properties by microwave heating, Microporous and Mesoporous Materials, 152 (2012) 78-83.

[39] H. Yi, H. Deng, X. Tang, Q. Yu, X. Zhou, H. Liu, Adsorption equilibrium and kinetics for $\mathrm{SO}_{2}, \mathrm{NO}, \mathrm{CO}_{2}$ on zeolites FAU and LTA, Journal of Hazardous Materials, 203 (2012) 111117.

[40] M. Gonçalves, L. Sánchez-García, E.d. Oliveira Jardim, J. Silvestre-Albero, F. RodríguezReinoso, Ammonia removal using activated carbons: effect of the surface chemistry in dry and moist conditions, Environmental Science \& Technology, 45 (2011) 10605-10610.

[41] W. Feng, S. Kwon, E. Borguet, R. Vidic, Adsorption of hydrogen sulfide onto activated carbon fibers: Effect of pore structure and surface chemistry, Environmental Science \& Technology, 39 (2005) 9744-9749.

[42] D. Ramirez, S. Qi, M.J. Rood, K.J. Hay, Equilibrium and heat of adsorption for organic vapors and activated carbons, Environmental Science \& Technology, 39 (2005) 5864-5871.

[43] X. Zhou, H.H. Yi, X.L. Tang, H. Deng, H.Y. Liu, Thermodynamics for the adsorption of $\mathrm{SO}_{2}$, $\mathrm{NO}$ and $\mathrm{CO}_{2}$ from flue gas on activated carbon fiber, Chemical Engineering Journal, 200 (2012) 399-404.

[44] M. Seredych, T.J. Bandosz, Removal of ammonia by graphite oxide via its intercalation and reactive adsorption, Carbon, 45 (2007) 2130-2132.

[45] M. Seredych, T.J. Bandosz, Mechanism of ammonia retention on graphite oxides: Role of surface chemistry and structure, Journal of Physical Chemistry C, 111 (2007) 15596-15604.

[46] C. Petit, M. Seredych, T.J. Bandosz, Revisiting the chemistry of graphite oxides and its effect on ammonia adsorption, Journal of Materials Chemistry, 19 (2009) 9176-9185.

[47] M. Seredych, J.A. Rossin, T.J. Bandosz, Changes in graphite oxide texture and chemistry upon oxidation and reduction and their effect on adsorption of ammonia, Carbon, 49 (2011) 43924402.

[48] S. Tang, Z. Cao, Adsorption and dissociation of ammonia on graphene oxides: A firstprinciples study, The Journal of Physical Chemistry C, 116 (2012) 8778-8791.

[49] C. Petit, T.J. Bandosz, Graphite oxide/polyoxometalate nanocomposites as adsorbents of ammonia, The Journal of Physical Chemistry C, 113 (2009) 3800-3809.

[50] M. Seredych, T.J. Bandosz, Graphite oxide/AlZr polycation composites: Surface characterization and performance as adsorbents of ammonia, Materials Chemistry and Physics, 117 (2009) 99-106. 
[51] M. Seredych, T.J. Bandosz, Manganese oxide and graphite oxide/ $\mathrm{MnO}_{2}$ composites as reactive adsorbents of ammonia at ambient conditions, Microporous and Mesoporous Materials, 150 (2012) 55-63.

[52] C. Petit, B. Mendoza, T.J. Bandosz, Reactive adsorption of ammonia on Cu-based MOF/graphene composites, Langmuir, 26 (2010) 15302-15309.

[53] M. Seredych, T.J. Bandosz, Effects of surface features on adsorption of $\mathrm{SO}_{2}$ on graphite oxide/ $\mathrm{ZrOH}_{4}$ composites, Journal of Physical Chemistry C, 114 (2010) 14552-14560.

[54] C. Petit, B. Mendoza, T.J. Bandosz, Hydrogen sulfide adsorption on MOFs and MOF/graphite oxide composites, Chemphyschem, 11 (2010) 3678-3684.

[55] O. Mabayoje, M. Seredych, T.J. Bandosz, Enhanced reactive adsorption of hydrogen sulfide on the composites of graphene/graphite oxide with copper (Hydr)oxychlorides, Acs Applied Materials \& Interfaces, 4 (2012) 3316-3324.

[56] S. Wang, H.M. Ang, M.O. Tade, Volatile organic compounds in indoor environment and photocatalytic oxidation: State of the art, Environment International, 33 (2007) 694-705.

[57] Y. Matsuo, Y. Nishino, T. Fukutsuka, Y. Sugie, Introduction of amino groups into the interlayer space of graphite oxide using 3-aminopropylethoxysilanes, Carbon, 45 (2007) 1384-1390.

[58] Y. Matsuo, Y. Nishino, T. Fukutsuka, Y. Sugie, Removal of formaldehyde from gas phase by silylated graphite oxide containing amino groups, Carbon, 46 (2008) 1162-1163.

[59] A. Dabrowski, P. Podkoscielny, Z. Hubicki, M. Barczak, Adsorption of phenolic compounds by activated carbon - a critical review, Chemosphere, 58 (2005) 1049-1070.

[60] D. Mohan, C.U. Pittman, Jr., Activated carbons and low cost adsorbents for remediation of triand hexavalent chromium from water, Journal of Hazardous Materials, 137 (2006) 762-811.

[61] K.Y. Foo, B.H. Hameed, Detoxification of pesticide waste via activated carbon adsorption process, Journal of Hazardous Materials, 175 (2010) 1-11.

[62] V.K.K. Upadhyayula, S. Deng, M.C. Mitchell, G.B. Smith, Application of carbon nanotube technology for removal of contaminants in drinking water: A review, Science of the Total Environment, 408 (2009) 1-13.

[63] S.-T. Yang, Y. Chang, H. Wang, G. Liu, S. Chen, Y. Wang, Y. Liu, A. Cao, Folding/aggregation of graphene oxide and its application in $\mathrm{Cu}^{2+}$ removal, Journal of Colloid and Interface Science, 351 (2010) 122-127.

[64] G. Zhao, J. Li, X. Ren, C. Chen, X. Wang, Few-layered graphene oxide nanosheets as superior sorbents for heavy metal ion pollution management, Environmental Science \& Technology, 45 (2011) 10454-10462.

[65] G. Zhao, X. Ren, X. Gao, X. Tan, J. Li, C. Chen, Y. Huang, X. Wang, Removal of Pb(II) ions from aqueous solutions on few-layered graphene oxide nanosheets, Dalton Transactions, 40 (2011) 10945-10952.

[66] G. Zhao, T. Wen, X. Yang, S. Yang, J. Liao, J. Hu, D. Shao, X. Wang, Preconcentration of $\mathrm{U}(\mathrm{VI})$ ions on few-layered graphene oxide nanosheets from aqueous solutions, Dalton Transactions, 41 (2012) 6182-6188.

[67] W. Gao, M. Majumder, L.B. Alemany, T.N. Narayanan, M.A. Ibarra, B.K. Pradhan, P.M. Ajayan, Engineered graphite oxide materials for application in water purification, ACS Applied Materials \& Interfaces, 3 (2011) 1821-1826.

[68] C.J. Madadrang, H.Y. Kim, G. Gao, N. Wang, J. Zhu, H. Feng, M. Gorring, M.L. Kasner, S. Hou, Adsorption behavior of EDTA-graphene oxide for $\mathrm{Pb}$ (II) removal, ACS Applied Materials \& Interfaces, 4 (2012) 1186-1193.

[69] Y.Q. He, N.N. Zhang, X.D. Wang, Adsorption of graphene oxide/chitosan porous materials for metal ions, Chinese Chemical Letters, 22 (2011) 859-862.

[70] N. Zhang, H. Qiu, Y. Si, W. Wang, J. Gao, Fabrication of highly porous biodegradable monoliths strengthened by graphene oxide and their adsorption of metal ions, Carbon, 49 (2011) 827-837. 
[71] L. Liu, C. Li, C. Bao, Q. Jia, P. Xiao, X. Liu, Q. Zhang, Preparation and characterization of chitosan/graphene oxide composites for the adsorption of $\mathrm{Au}(\mathrm{III})$ and $\mathrm{Pd}(\mathrm{II})$, Talanta, 93 (2012) 350-357.

[72] Y.-C. Lee, J.-W. Yang, Self-assembled flower-like $\mathrm{TiO}_{2}$ on exfoliated graphite oxide for heavy metal removal, Journal of Industrial and Engineering Chemistry, 18 (2012) 1178-1185.

[73] H. Sun, L. Cao, L. Lu, Magnetite/reduced graphene oxide nanocomposites: One step solvothermal synthesis and use as a novel platform for removal of dye pollutants, Nano Research, 4 (2011) 550-562.

[74] M. Liu, C. Chen, J. Hu, X. Wu, X. Wang, Synthesis of magnetite/graphene oxide composite and application for cobalt(II) removal, Journal of Physical Chemistry C, 115 (2011) 2523425240.

[75] M. Machida, T. Mochimaru, H. Tatsumoto, Lead(II) adsorption onto the graphene layer of carbonaceous materials in aqueous solution, Carbon, 44 (2006) 2681-2688.

[76] Z.-H. Huang, X. Zheng, W. Lv, M. Wang, Q.-H. Yang, F. Kang, Adsorption of lead(II) ions from aqueous solution on low-temperature exfoliated graphene nanosheets, Langmuir, 27 (2011) 7558-7562.

[77] X. Deng, L. Lue, H. Li, F. Luo, The adsorption properties of $\mathrm{Pb}$ (II) and $\mathrm{Cd}(\mathrm{II})$ on functionalized graphene prepared by electrolysis method, Journal of Hazardous Materials, 183 (2010) 923-930.

[78] L. Hao, H. Song, L. Zhang, X. Wan, Y. Tang, Y. Lv, $\mathrm{SiO}_{2}$ /graphene composite for highly selective adsorption of $\mathrm{Pb}(\mathrm{II})$ ion, Journal of Colloid and Interface Science, 369 (2012) 381387.

[79] V. Chandra, K.S. Kim, Highly selective adsorption of $\mathrm{Hg}^{2+}$ by a polypyrrole-reduced graphene oxide composite, Chemical Communications, 47 (2011) 3942-3944.

[80] T.S. Sreeprasad, S.M. Maliyekkal, K.P. Lisha, T. Pradeep, Reduced graphene oxidemetal/metal oxide composites: Facile synthesis and application in water purification, Journal of Hazardous Materials, 186 (2011) 921-931.

[81] Y. Ren, N. Yan, Q. Wen, Z. Fan, T. Wei, M. Zhang, J. Ma, Graphene/ $\delta-\mathrm{MnO}_{2}$ composite as adsorbent for the removal of nickel ions from wastewater, Chemical Engineering Journal, 175 (2011) 1-7.

[82] A.K. Mishra, S. Ramaprabhu, Functionalized graphene sheets for arsenic removal and desalination of sea water, Desalination, 282 (2011) 39-45.

[83] V. Chandra, J. Park, Y. Chun, J.W. Lee, I.-C. Hwang, K.S. Kim, Water-dispersible magnetitereduced graphene oxide composites for arsenic removal, ACS Nano, 4 (2010) 3979-3986.

[84] K. Zhang, V. Dwivedi, C. Chi, J. Wu, Graphene oxide/ferric hydroxide composites for efficient arsenate removal from drinking water, Journal of Hazardous Materials, 182 (2010) 162-168.

[85] X.-L. Wu, L. Wang, C.-L. Chen, A.-W. Xu, X.-K. Wang, Water-dispersible magnetitegraphene-LDH composites for efficient arsenate removal, Journal of Materials Chemistry, 21 (2011) 17353-17359.

[86] H.-L. Ma, Y. Zhang, Q.-H. Hu, D. Yan, Z.-Z. Yu, M. Zhai, Chemical reduction and removal of $\mathrm{Cr}(\mathrm{VI})$ from acidic aqueous solution by ethylenediamine-reduced graphene oxide, Journal of Materials Chemistry, 22 (2012) 5914-5916.

[87] H. Jabeen, V. Chandra, S. Jung, J.W. Lee, K.S. Kim, S. Bin Kim, Enhanced Cr(VI) removal using iron nanoparticle decorated graphene, Nanoscale, 3 (2011) 3583-3585.

[88] J. Zhu, S. Wei, H. Gu, S.B. Rapole, Q. Wang, Z. Luo, N. Haldolaarachchige, D.P. Young, Z. Guo, One-pot synthesis of magnetic graphene nanocomposites decorated with core@ doubleshell nanoparticles for fast chromium removal, Environmental Science \& Technology, 46 (2011) 977-985.

[89] Y. Li, P. Zhang, Q. Du, X. Peng, T. Liu, Z. Wang, Y. Xia, W. Zhang, K. Wang, H. Zhu, D. $\mathrm{Wu}$, Adsorption of fluoride from aqueous solution by graphene, Journal of Colloid and Interface Science, 363 (2011) 348-354. 
[90] S. Zhang, Y. Shao, J. Liu, I.A. Aksay, Y. Lin, Graphene-polypyrrole nanocomposite as a highly efficient and low cost electrically switched ion exchanger for removing $\mathrm{ClO}_{4}{ }^{-}$from wastewater, Acs Applied Materials \& Interfaces, 3 (2011) 3633-3637.

[91] S. Vasudevan, J. Lakshmi, The adsorption of phosphate by graphene from aqueous solution, RSC Advances, 2 (2012) 5234-5242.

[92] P. Bradder, S.K. Ling, S. Wang, S. Liu, Dye adsorption on layered graphite oxide, Journal of Chemical and Engineering Data, 56 (2011) 138-141.

[93] S.-T. Yang, S. Chen, Y. Chang, A. Cao, Y. Liu, H. Wang, Removal of methylene blue from aqueous solution by graphene oxide, Journal of Colloid and Interface Science, 359 (2011) 24 29.

[94] W. Zhang, C. Zhou, W. Zhou, A. Lei, Q. Zhang, Q. Wan, B. Zou, Fast and considerable adsorption of methylene blue dye onto graphene oxide, Bulletin of Environmental Contamination and Toxicology, 87 (2011) 86-90.

[95] F. Liu, S. Chung, G. Oh, T.S. Seo, Three-dimensional graphene oxide nanostructure for fast and efficient water-soluble dye removal, Acs Applied Materials \& Interfaces, 4 (2012) 922927.

[96] T. Liu, Y. Li, Q. Du, J. Sun, Y. Jiao, G. Yang, Z. Wang, Y. Xia, W. Zhang, K. Wang, H. Zhu, $\mathrm{D}$. Wu, Adsorption of methylene blue from aqueous solution by graphene, Colloids and Surfaces B-Biointerfaces, 90 (2012) 197-203.

[97] Y.H. Li, T. Liu, Q. Du, J. Sun, Y. Xia, Z. Wang, W. Zhang, K. Wang, H. Zhu, D. Wu, Adsorption of cationic red X-GRL from aqueous solutions by graphene: Equilibrium, kinetics and thermodynamics study, Chemical and Biochemical Engineering Quarterly, 25 (2011) 483-491.

[98] L. Sun, H. Yu, B. Fugetsu, Graphene oxide adsorption enhanced by in situ reduction with sodium hydrosulfite to remove acridine orange from aqueous solution, Journal of Hazardous Materials, 203-204 (2012) 101-110.

[99] G.K. Ramesha, A.V. Kumara, H.B. Muralidhara, S. Sampath, Graphene and graphene oxide as effective adsorbents toward anionic and cationic dyes, Journal of Colloid and Interface Science, 361 (2011) 270-277.

[100] Z. Sui, Q. Meng, X. Zhang, R. Ma, B. Cao, Green synthesis of carbon nanotube-graphene hybrid aerogels and their use as versatile agents for water purification, Journal of Materials Chemistry, 22 (2012) 8767-8771.

[101] J.-S. Cheng, J. Du, W. Zhu, Facile synthesis of three-dimensional chitosan-graphene mesostructures for reactive black 5 removal, Carbohydrate Polymers, 88 (2012) 61-67.

[102] N.-P. Thuy-Duong, P. Viet Hung, E.J. Kim, E.-S. Oh, S.H. Hur, J.S. Chung, B. Lee, E.W. Shin, Reduced graphene oxide-titanate hybrids: Morphologic evolution by alkalisolvothermal treatment and applications in water purification, Applied Surface Science, 258 (2012) 4551-4557.

[103] B. Li, H. Cao, G. Yin, Y. Lu, J. Yin, Cu2O@reduced graphene oxide composite for removal of contaminants from water and supercapacitors, Journal of Materials Chemistry, 21 (2011) 10645-10648.

[104] B. Li, H. Cao, G. Yin, $\mathrm{Mg}(\mathrm{OH})_{2} @$ reduced graphene oxide composite for removal of dyes from water, Journal of Materials Chemistry, 21 (2011) 13765-13768.

[105] G. Xie, P. Xi, H. Liu, F. Chen, L. Huang, Y. Shi, F. Hou, Z. Zeng, C. Shao, J. Wang, A facile chemical method to produce superparamagnetic graphene oxide- $\mathrm{Fe}_{3} \mathrm{O}_{4}$ hybrid composite and its application in the removal of dyes from aqueous solution, Journal of Materials Chemistry, 22 (2012) 1033-1039.

[106] L. Ai, C. Zhang, Z. Chen, Removal of methylene blue from aqueous solution by a solvothermal-synthesized graphene/magnetite composite, Journal of Hazardous Materials, 192 (2011) 1515-1524. 
[107] Z. Geng, Y. Lin, X. Yu, Q. Shen, L. Ma, Z. Li, N. Pan, X. Wang, Highly efficient dye adsorption and removal: a functional hybrid of reduced graphene oxide- $\mathrm{Fe}_{3} \mathrm{O}_{4}$ nanoparticles as an easily regenerative adsorbent, Journal of Materials Chemistry, 22 (2012) 3527-3535.

[108] C. Wang, C. Feng, Y. Gao, X. Ma, Q. Wu, Z. Wang, Preparation of a graphene-based magnetic nanocomposite for the removal of an organic dye from aqueous solution, Chemical Engineering Journal, 173 (2011) 92-97.

[109] Y. Yao, S. Miao, S. Liu, L.P. Ma, H. Sun, S. Wang, Synthesis, characterization, and adsorption properties of magnetic $\mathrm{Fe}_{3} \mathrm{O}_{4} @$ graphene nanocomposite, Chemical Engineering Journal, 184 (2012) 326-332.

[110] N. Li, M. Zheng, X. Chang, G. Ji, H. Lu, L. Xue, L. Pan, J. Cao, Preparation of magnetic $\mathrm{CoFe} 2 \mathrm{O} 4$-functionalized graphene sheets via a facile hydrothermal method and their adsorption properties, Journal of Solid State Chemistry, 184 (2011) 953-958.

[111] S. Bai, X. Shen, X. Zhong, Y. Liu, G. Zhu, X. Xu, K. Chen, One-pot solvothermal preparation of magnetic reduced graphene oxide-ferrite hybrids for organic dye removal, Carbon, 50 (2012) 2337-2346.

[112] Y. Yao, S. Miao, L. Ping Ma, H. Sun, S. Wang, Fabrication of $\mathrm{Fe}_{3} \mathrm{O}_{4} / \mathrm{SiO}_{2}$ core/shell nanoparticles attached to graphene-oxide and its use as an adsorbent, Journal of Colloid and Interface Science, (2012).

[113] J. Guo, R. Wang, W.W. Tjiu, J. Pan, T. Liu, Synthesis of Fe nanoparticles@graphene composites for environmental applications, Journal of Hazardous Materials, 225-226 (2012) 63-73.

[114] L. Fan, C. Luo, X. Li, F. Lu, H. Qiu, M. Sun, Fabrication of novel magnetic chitosan grafted with graphene oxide to enhance adsorption properties for methyl blue, Journal of Hazardous Materials, 215-216 (2012) 272-279.

[115] L. Fan, C. Luo, M. Sun, X. Li, F. Lu, H. Qiu, Preparation of novel magnetic chitosan/graphene oxide composite as effective adsorbents toward methylene blue, Bioresource Technology, 114 (2012) 703-706.

[116] S.B. Wang, C.W. Ng, W.T. Wang, Q. Li, Z.P. Hao, Synergistic and competitive adsorption of organic dyes on multiwalled carbon nanotubes, Chemical Engineering Journal, 197 (2012) $34-40$.

[117] T. Hartono, S. Wang, Q. Ma, Z. Zhu, Layer structured graphite oxide as a novel adsorbent for humic acid removal from aqueous solution, Journal of Colloid and Interface Science, 333 (2009) 114-119.

[118] Y. Gao, Y. Li, L. Zhang, H. Huang, J. Hu, S.M. Shah, X. Su, Adsorption and removal of tetracycline antibiotics from aqueous solution by graphene oxide, Journal of Colloid and Interface Science, 368 (2012) 540-546.

[119] T. Wu, X. Cai, S. Tan, H. Li, J. Liu, W. Yang, Adsorption characteristics of acrylonitrile, ptoluenesulfonic acid, 1-naphthalenesulfonic acid and methyl blue on graphene in aqueous solutions, Chemical Engineering Journal, 173 (2011) 144-149.

[120] Y. Li, Q. Du, T. Liu, J. Sun, Y. Jiao, Y. Xia, L. Xia, Z. Wang, W. Zhang, K. Wang, H. Zhu, D. $\mathrm{Wu}$, Equilibrium, kinetic and thermodynamic studies on the adsorption of phenol onto graphene, Materials Research Bulletin, 47 (2012) 1898-1904.

[121] J. Xu, L. Wang, Y. Zhu, Decontamination of bisphenol A from aqueous solution by graphene adsorption, Langmuir, (2012).

[122] Z. Pei, L. Li, L. Sun, S. Zhang, X.-q. Shan, S. Yang, B. Wen, Adsorption characteristics of 1,2,4-trichlorobenzene, 2,4,6-trichlorophenol, 2-naphthol and naphthalene on graphene and graphene oxide, Carbon, 51 (2013) 156-163.

[123] S.M. Maliyekkal, T.S. Sreeprasad, D. Krishnan, S. Kouser, A.K. Mishra, U.V. Waghmare, T. Pradeep, Graphene: A Reusable Substrate for Unprecedented Adsorption of Pesticides, Small, 9 (2013) 273-283. 
[124] S. Sen Gupta, T.S. Sreeprasad, S.M. Maliyekkal, S.K. Das, T. Pradeep, Graphene from Sugar and its Application in Water Purification, ACS Applied Materials \& Interfaces, 4 (2012) 4156-4163.

[125] X. Hu, L. Mu, J. Wen, Q. Zhou, Immobilized smart RNA on graphene oxide nanosheets to specifically recognize and adsorb trace peptide toxins in drinking water, Journal of Hazardous Materials, 213-214 (2012) 387-392.

[126] G. Zhao, L. Jiang, Y. He, J. Li, H. Dong, X. Wang, W. Hu, Sulfonated graphene for persistent aromatic pollutant management, Advanced Materials, 23 (2011) 3959-3963.

[127] G. Zhao, J. Li, X. Wang, Kinetic and thermodynamic study of 1-naphthol adsorption from aqueous solution to sulfonated graphene nanosheets, Chemical Engineering Journal, 173 (2011) 185-190.

[128] Q. Wu, G. Zhao, C. Feng, C. Wang, Z. Wang, Preparation of a graphene-based magnetic nanocomposite for the extraction of carbamate pesticides from environmental water samples, Journal of Chromatography A, 1218 (2011) 7936-7942.

[129] S. Li, Z. Niu, X. Zhong, H. Yang, Y. Lei, F. Zhang, W. Hu, Z. Dong, J. Jin, J. Ma, Fabrication of magnetic $\mathrm{Ni}$ nanoparticles functionalized water-soluble graphene sheets nanocomposites as sorbent for aromatic compounds removal, Journal of Hazardous Materials, 229-230 (2012) 42-47.

[130] Y.W. Zhu, S. Murali, M.D. Stoller, K.J. Ganesh, W.W. Cai, P.J. Ferreira, A. Pirkle, R.M. Wallace, K.A. Cychosz, M. Thommes, D. Su, E.A. Stach, R.S. Ruoff, Carbon-Based Supercapacitors Produced by Activation of Graphene, Science, 332 (2011) 1537-1541.

[131] S. Murali, J.R. Potts, S. Stoller, J. Park, M.D. Stoner, L.L. Zhang, Y.W. Zhu, R.S. Ruoff, Preparation of activated graphene and effect of activation parameters on electrochemical capacitance, Carbon, 50 (2012) 3482-3485.

[132] W. Peng, S. Liu, H. Sun, Y. Yao, L. Zhi, S. Wang, Synthesis of porous reduced graphene oxide as metal-free carbon for adsorption and catalytic oxidation of organics in water, Journal of Materials Chemistry A, DOI: 10.1039/C3TA10592J (2013).

[133] L. Ai, J. Jiang, Removal of methylene blue from aqueous solution with self-assembled cylindrical graphene-carbon nanotube hybrid, Chemical Engineering Journal, 192 (2012) 156163. 


\section{List of Tables}

Table 1 Metal adsorption capacity on graphene-based materials.

\begin{tabular}{|c|c|c|c|c|}
\hline Adsorbent & GO reduction & Metal & Adsorption $(\mathrm{mg} / \mathrm{g})$ & Ref \\
\hline GO & - & $\mathrm{Cu}(\mathrm{II})$ & 46.6(RT) & [63] \\
\hline GO-gelatin/Chitosan & - & $\mathrm{Cu}(\mathrm{II})$ & 120 (RT) & [70] \\
\hline GO & - & $\mathrm{Cd}(\mathrm{II})$ & $106.3\left(30^{\circ} \mathrm{C}\right)$ & [64] \\
\hline GO & - & $\mathrm{Cd}(\mathrm{II})$ & $14.9(\mathrm{RT})$ & [72] \\
\hline $\mathrm{TiO}_{2} / \mathrm{GO}$ & - & $\mathrm{Cd}(\mathrm{II})$ & 72.8 & [72] \\
\hline $\mathrm{GNs}^{\mathrm{C} 8 \mathrm{P}}$ & - & $\mathrm{Cd}(\mathrm{II})$ & $30.0(\mathrm{RT})$ & {$[77]$} \\
\hline $\mathrm{GNs}^{\mathrm{PF} 6}$ & - & $\mathrm{Cd}(\mathrm{II})$ & $73.4(\mathrm{RT})$ & [77] \\
\hline GO & - & $\mathrm{Co}(\mathrm{II})$ & $68.2\left(30^{\circ} \mathrm{C}\right)$ & [64] \\
\hline $\mathrm{Fe}_{3} \mathrm{O}_{4} / \mathrm{GO}$ & - & $\mathrm{Co}(\mathrm{II})$ & $13.0-22.7\left(30-70^{\circ} \mathrm{C}\right)$ & [74] \\
\hline GO & - & $\mathrm{Zn}$ (II) & $30.1(\mathrm{RT})$ & [72] \\
\hline $\mathrm{TiO}_{2} / \mathrm{GO}$ & - & $\mathrm{Zn}(\mathrm{II})$ & 88.9 & [72] \\
\hline GO & - & $\mathrm{Pb}(\mathrm{II})$ & $35.6(\mathrm{RT})$ & [72] \\
\hline GO & - & $\mathrm{Pb}(\mathrm{II})$ & $842-1850\left(20-60^{\circ} \mathrm{C}\right)$ & [65] \\
\hline GO & - & $\mathrm{Pb}(\mathrm{II})$ & $367\left(25^{\circ} \mathrm{C}\right)$ & [68] \\
\hline GO-EDTA & - & $\mathrm{Pb}(\mathrm{II})$ & $479\left(25^{\circ} \mathrm{C}\right)$ & [68] \\
\hline GO/Chitosan & - & $\mathrm{Pb}(\mathrm{II})$ & $99(\mathrm{RT})$ & [69] \\
\hline GO-gelatin/Chitosan & & $\mathrm{Pb}(\mathrm{II})$ & $100(\mathrm{RT})$ & [70] \\
\hline $\mathrm{TiO}_{2} / \mathrm{GO}$ & _- & $\mathrm{Pb}(\mathrm{II})$ & 65.6 & [72] \\
\hline GNs & $200^{\circ}$ & $\mathrm{Pb}(\mathrm{II})$ & $22.4\left(30^{\circ} \mathrm{C}\right)$ & [76] \\
\hline GNs-500 & Vacuum, $200^{\circ} \mathrm{C}$ & $\mathrm{Pb}(\mathrm{II})$ & $35.2\left(30^{\circ} \mathrm{C}\right)$ & [76] \\
\hline GNs-700 & Vacuum, $200^{\circ} \mathrm{C}$ & $\mathrm{Pb}(\mathrm{II})$ & $35.5\left(30^{\circ} \mathrm{C}\right)$ & [76] \\
\hline GNs-EDTA & Water & $\mathrm{Pb}(\mathrm{II})$ & $228\left(25^{\circ} \mathrm{C}\right)$ & {$[68]$} \\
\hline $\mathrm{GNs}^{\mathrm{C} 8 \mathrm{P}}$ & - & $\mathrm{Pb}(\mathrm{II})$ & $74.2(\mathrm{RT})$ & [77] \\
\hline $\mathrm{GNs}^{\mathrm{PF} 6}$ & - & $\mathrm{Pb}(\mathrm{II})$ & $405.9(\mathrm{RT})$ & [77] \\
\hline $\mathrm{SiO}_{2}-\mathrm{GNS}$ & Hydrazine & $\mathrm{Pb}(\mathrm{II})$ & $113.6\left(25^{\circ} \mathrm{C}\right)$ & [78] \\
\hline $\mathrm{GO}$ & - & $\operatorname{Hg}(\mathrm{II})$ & $35(\mathrm{RT})$ & [67] \\
\hline GO-SH & - & $\mathrm{Hg}(\mathrm{II})$ & $190(\mathrm{RT})$ & [67] \\
\hline GNs-SH & $\begin{array}{l}\text { Sodium } \\
\text { dodecylsulfate }\end{array}$ & $\mathrm{Hg}(\mathrm{II})$ & $22(\mathrm{RT})$ & [67] \\
\hline GNs-polypyrrole & Hydrazine & $\mathrm{Hg}(\mathrm{II})$ & $980\left(20^{\circ} \mathrm{C}\right)$ & [79] \\
\hline $\mathrm{MnO}_{2} / \mathrm{GNs}$ & Hydrazine & $\mathrm{Hg}(\mathrm{II})$ & $10.8\left(30^{\circ} \mathrm{C}\right)$ & [80] \\
\hline $\mathrm{Ag} / \mathrm{GNs}$ & Hydrazine & $\mathrm{Hg}(\mathrm{II})$ & $10.9\left(30^{\circ} \mathrm{C}\right)$ & {$[80]$} \\
\hline$\delta-\mathrm{MnO}_{2} / \mathrm{GNs}$ & Hydrazine & $\mathrm{Ni}(\mathrm{II})$ & $46.5-66.0\left(25-45^{\circ} \mathrm{C}\right)$ & [81] \\
\hline $\mathrm{Fe}_{3} \mathrm{O}_{4} / \mathrm{GNs} / \mathrm{LDH}$ & - & $\operatorname{As}(\mathrm{V})$ & 73.1 & [85] \\
\hline GNs & Hydrogen & $\mathrm{As}(\mathrm{III})$ & $138(\mathrm{RT})$ & [82] \\
\hline $\mathrm{Fe}_{3} \mathrm{O}_{4} / \mathrm{GNs}$ & Hydrazine & $\mathrm{As}(\mathrm{III})$ & 13.1 & [83] \\
\hline GNs & Sodium & $\mathrm{Cr}(\mathrm{VI})$ & $43\left(20^{\circ} \mathrm{C}\right)$ & [87] \\
\hline
\end{tabular}




\begin{tabular}{lllll} 
& $\begin{array}{l}\text { borohydride } \\
\text { Sedium }\end{array}$ & $\mathrm{Cr}(\mathrm{VI})$ & $162.6\left(20^{\circ} \mathrm{C}\right)$ & {$[87]$} \\
& $\begin{array}{l}\text { borohydride } \\
\mathrm{ED}-\mathrm{RGO}\end{array}$ & $\mathrm{Cr}(\mathrm{VI})$ & $5.0\left(33^{\circ} \mathrm{C}\right)$ & {$[86]$} \\
$\mathrm{Fe}^{0} / \mathrm{Fe}_{2} \mathrm{O}_{3} / \mathrm{Si}-\mathrm{S}-\mathrm{O}-$ & - & $\mathrm{Cr}(\mathrm{VI})$ & $1.0(\mathrm{RT})$ & {$[88]$} \\
$\mathrm{GNs}$ & - & & & \\
\hline $\mathrm{RT}:$ room temperature & & &
\end{tabular}

Table 2 Dye adsorption capacity on graphene-based materials.

\begin{tabular}{|c|c|c|c|c|}
\hline Adsorbent & GO reduction & Dye & Adsorption (mg/g) & Ref \\
\hline GO & - & MB & 351 & {$[92]$} \\
\hline GO & - & MB & 714 & [93] \\
\hline GO & - & MB & 1939 & [94] \\
\hline GO sponge & - & MB & 397 & [95] \\
\hline $\mathrm{Fe}_{3} \mathrm{O}_{4}-\mathrm{GO}$ & - & $\mathrm{MB}$ & $167.2\left(25^{\circ} \mathrm{C}\right)$ & {$[105]$} \\
\hline $\mathrm{Fe}_{3} \mathrm{O}_{4} / \mathrm{SiO}_{2}-\mathrm{GO}$ & $\mathrm{NH}_{3}$ & $\mathrm{MB}$ & $97.0-111.1\left(25-60^{\circ} \mathrm{C}\right)$ & {$[112]$} \\
\hline GNs & Hydrazine & $\mathrm{MB}$ & $154-204\left(20-60^{\circ} \mathrm{C}\right)$ & [96] \\
\hline G-aerogel & Vitamin C & $\mathrm{MB}$ & $152.8(\mathrm{RT})$ & {$[100]$} \\
\hline $\mathrm{Fe}_{3} \mathrm{O}_{4}-\mathrm{GNs}$ & Hydrothermal & MB & $43.8\left(25^{\circ} \mathrm{C}\right)$ & {$[106]$} \\
\hline $\mathrm{Fe}_{3} \mathrm{O}_{4}-\mathrm{GNs}$ & $\mathrm{NH}_{3}$ & $\mathrm{MB}$ & 45.3 & [109] \\
\hline $\mathrm{TiO}_{2}-\mathrm{GNs}$ & $\mathrm{NaOH}$ & $\mathrm{MB}$ & 83.3 & {$[102]$} \\
\hline $\mathrm{MnFe}_{2} \mathrm{O}_{4}-\mathrm{GNs}$ & Polyethylene glycol & $\mathrm{MB}$ & $34.7\left(25^{\circ} \mathrm{C}\right)$ & {$[111]$} \\
\hline MCGO & - & MB & $180.83\left(30^{\circ} \mathrm{C}\right)$ & {$[114]$} \\
\hline CNT-GNs & & MB & 81.97 & {$[133]$} \\
\hline GNs & Hydrazine & X-GRL & $217-238\left(15-60^{\circ} \mathrm{C}\right)$ & [97] \\
\hline $\mathrm{GO}$ & - & $\mathrm{AO}$ & 1428 & [98] \\
\hline GNs & Sodium hydrosulfite & $\mathrm{AO}$ & 3333 & [98] \\
\hline $\mathrm{Fe}_{3} \mathrm{O}_{4}-\mathrm{GO}$ & - & NR & $171.3\left(25^{\circ} \mathrm{C}\right)$ & {$[105]$} \\
\hline G-aerogel & Vitamin C & $\mathrm{RB}$ & $133.6(\mathrm{RT})$ & {$[100]$} \\
\hline $\mathrm{Fe}_{3} \mathrm{O}_{4}-\mathrm{GNs}$ & Hydrothermal & $\mathrm{RB}$ & $13.2(\mathrm{RT})$ & {$[73]$} \\
\hline $\mathrm{MnFe}_{2} \mathrm{O}_{4}-\mathrm{GNs}$ & Polyethylene glycol & $\mathrm{RB}$ & $22.5\left(25^{\circ} \mathrm{C}\right)$ & {$[111]$} \\
\hline Sand-GNs & - & R6G & $55\left(30^{\circ} \mathrm{C}\right)$ & {$[124]$} \\
\hline $\mathrm{Fe}_{3} \mathrm{O}_{4}-\mathrm{GNs}$ & Hydrothermal & MG & $22(\mathrm{RT})$ & {$[73]$} \\
\hline $\mathrm{GO}$ & - & MG & 248 & {$[92]$} \\
\hline GO sponge & - & MV & 467 & [95] \\
\hline $\mathrm{CoFe}_{2} \mathrm{O}_{4}-\mathrm{GNs}$ & $\mathrm{NaOH}$ & MO & 71.5 & {$[110]$} \\
\hline G-aerogel & Vitamin $\mathrm{C}$ & Fuchsine & $142.7(\mathrm{RT})$ & {$[100]$} \\
\hline $\mathrm{Fe}_{3} \mathrm{O}_{4}-\mathrm{GNs}$ & Hydrazine/ $\mathrm{NH}_{3}$ & Fuchsine & 89.4 & [108] \\
\hline G-aerogel & Vitamin $\mathrm{C}$ & Acid Fuchsine & $43.2(\mathrm{RT})$ & {$[100]$} \\
\hline $\mathrm{Fe}_{3} \mathrm{O}_{4}-\mathrm{GNs}$ & $\mathrm{NH}_{3}$ & $\mathrm{CR}$ & 33.7 & {$[109]$} \\
\hline $\mathrm{Fe}-\mathrm{GNs}$ & $\mathrm{NaBH}_{4}$ & Methyl blue & $75-375(\mathrm{RT})$ & {$[113]$} \\
\hline $\mathrm{GO}$ & - & Methyl blue & $43.5\left(30^{\circ} \mathrm{C}\right)$ & {$[114]$} \\
\hline MCGO & - & Methyl blue & $95.2\left(30^{\circ} \mathrm{C}\right)$ & [114] \\
\hline
\end{tabular}




\section{List of Figures}
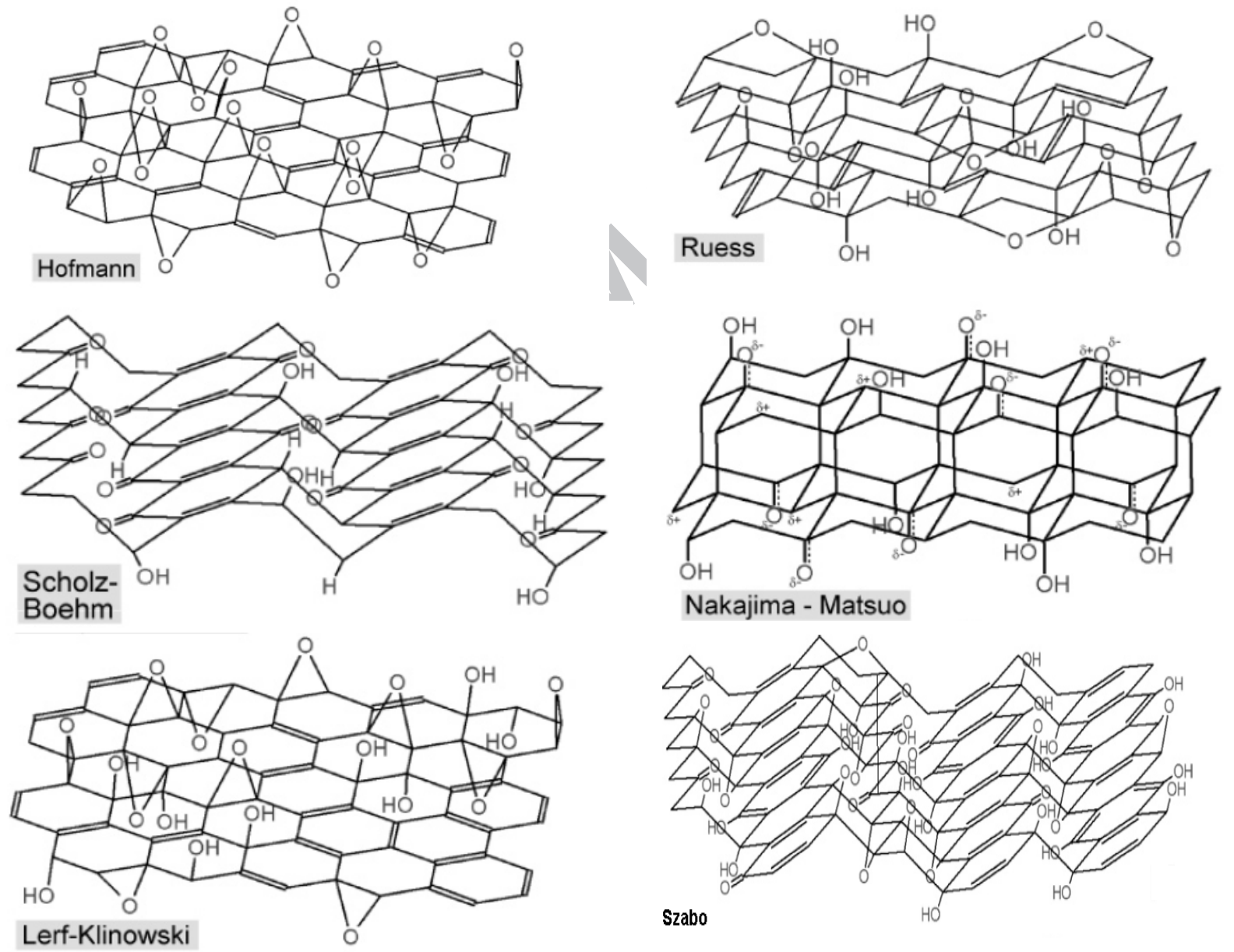

Fig.1 Various models of GO chemical structure. 

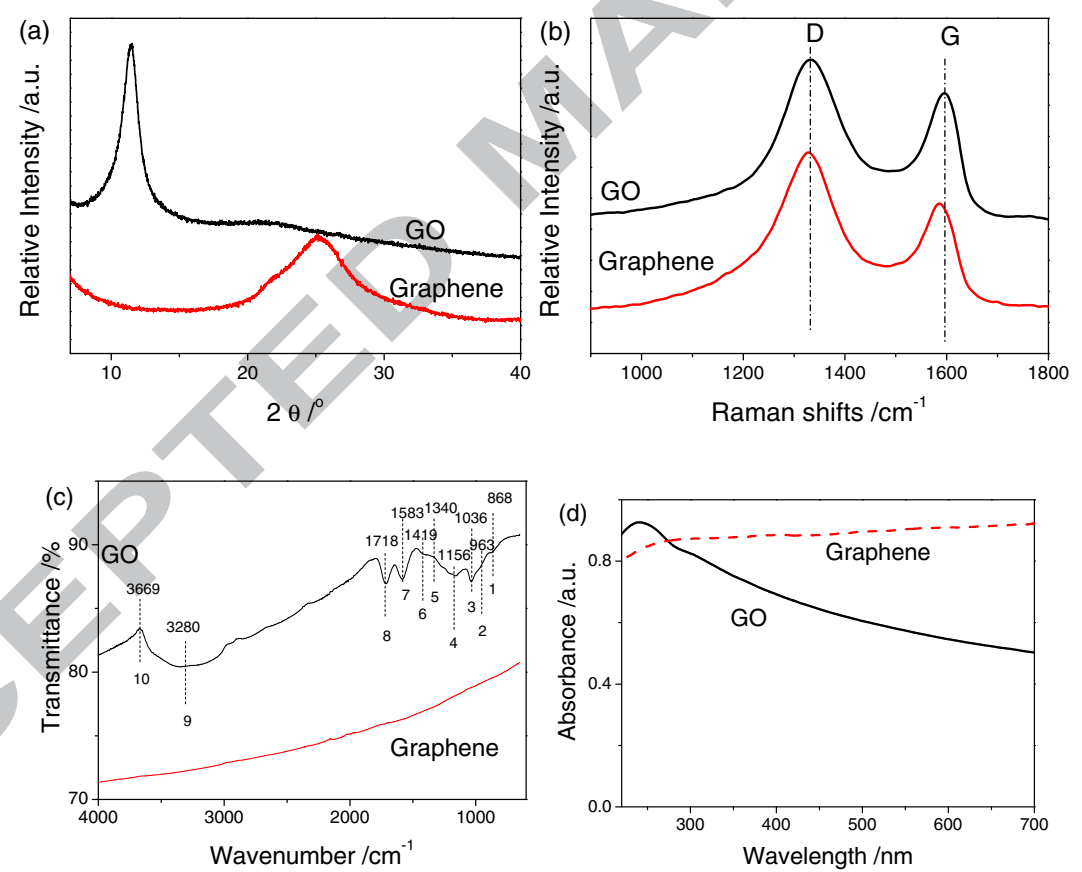

Fig.2 XRD patterns (a), Raman spectra (b), FTIR spectra (c) and UV-vis spectra (d) of GO and GNs. 


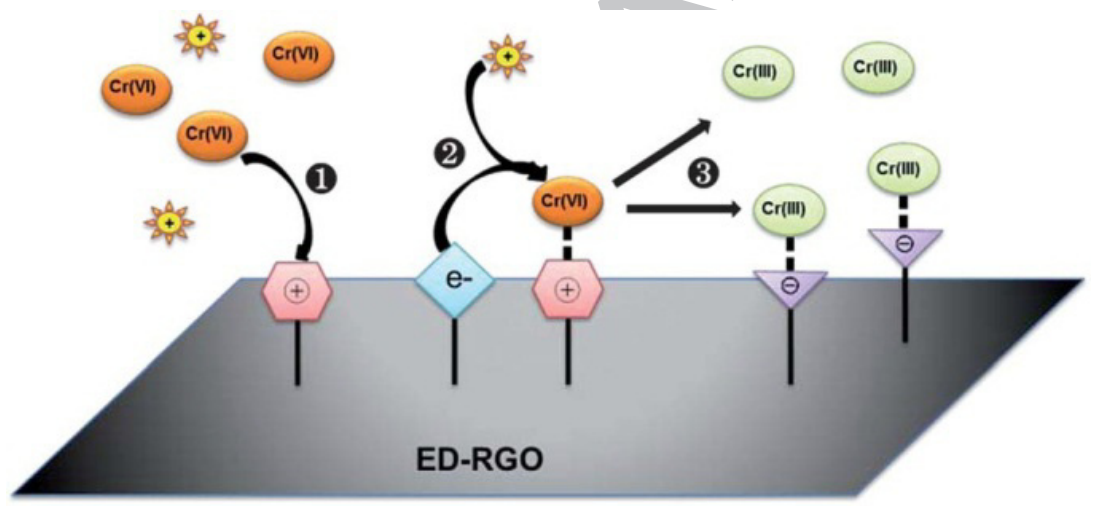

(CrVII) $\mathrm{HCrO}_{4}^{-} \oplus$ Protonated amino groups

Cr(III) $\mathrm{Cr}^{3+}$ e- Electron donor $\quad \theta \quad-\mathrm{COO}$

Fig.3 Proposed mechanism of $\mathrm{Cr}(\mathrm{VI})$ removal by ED-RGO[86]. 


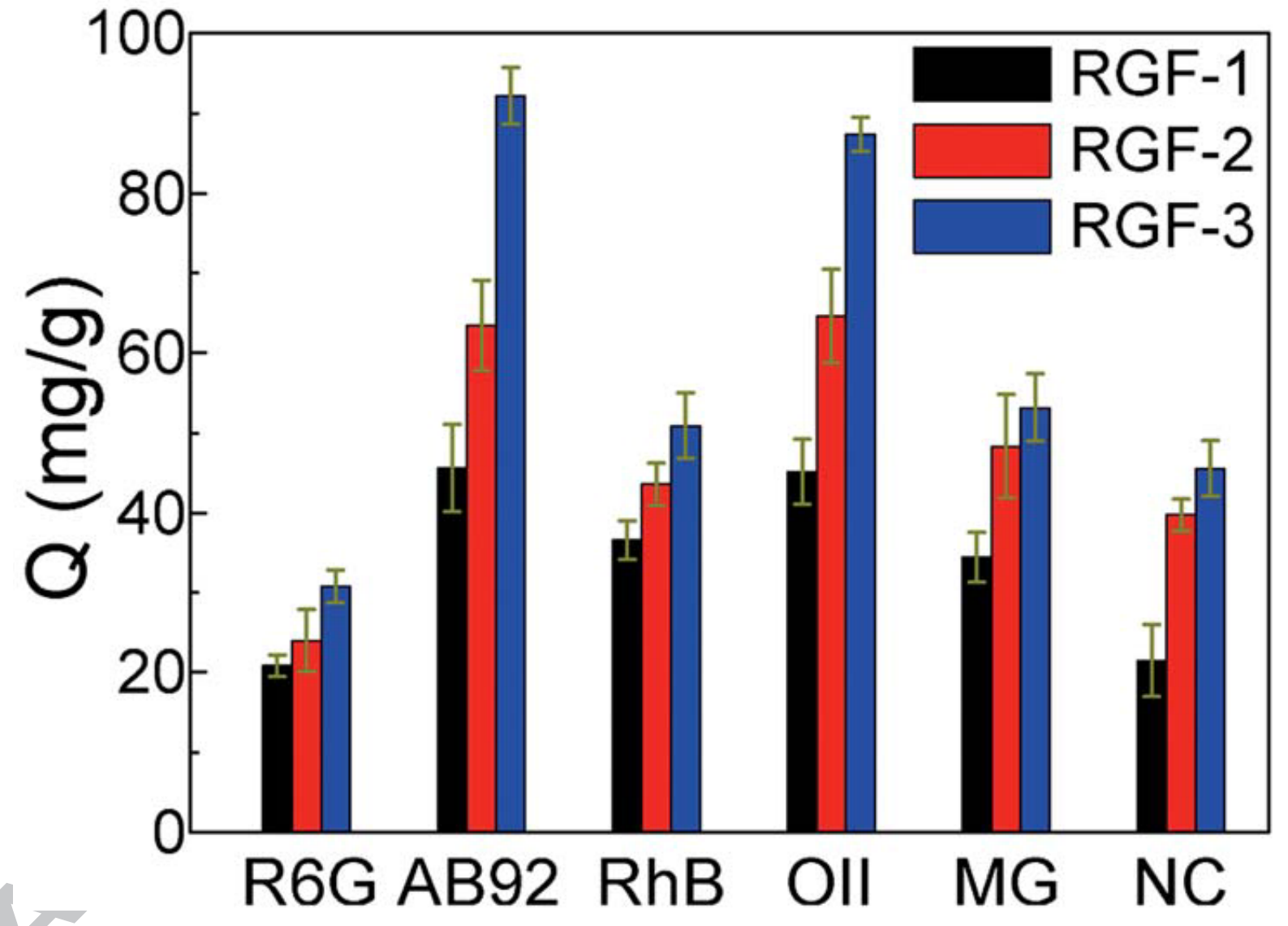

Fig. 4 The saturated adsorption capacity $(Q)$ values for all of these dyes using RGF-1 (black), RGF2 (red), and RGF-3 (blue) as the adsorbents. RGF-1, RGF-2 and RGF-3 are referred to composites at $\mathrm{C} / \mathrm{Fe}$ atomic ratios of 1.7:1, 3.0:1 and 7.0:1, respectively [107]. 


\section{Graphical abstract}

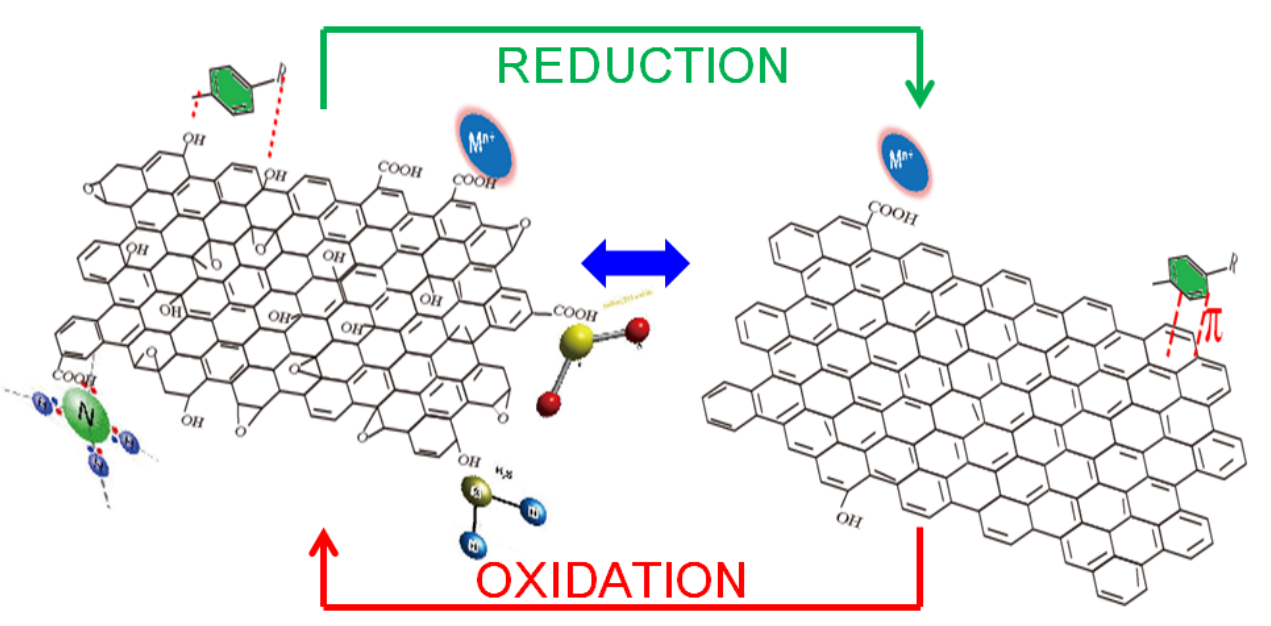




\section{Research Highlights}

Graphene-based materials present high adsorption capacity for water and air pollutants.

$>$ Graphene oxide exhibits high adsorption to basic and cationic compounds.

$>$ Strong $\pi-\pi$ interaction plays an important role for graphene adsorption.

$>$ Graphene functionalised composites show enhanced performance in adsorption. 